\title{
Consequences of mixing Acacia mangium and Eucalyptus grandis trees on soil exploration by fine-roots down to a depth of $17 \mathrm{~m}$
}

\author{
Amandine Germon • Iraê Amaral Guerrini • Bruno Bordron • Jean-Pierre Bouillet • \\ Yann Nouvellon • José Leonardo de Moraes Gonçalves • Christophe Jourdan • \\ Ranieri Ribeiro Paula • Jean-Paul Laclau (D)
}

Received: 24 April 2017 / Accepted: 13 September 2017 / Published online: 10 October 2017

(C) Springer International Publishing AG 2017

\begin{abstract}
Background and aims Fine-root functioning is a major driver of plant growth and strongly influences the global carbon cycle. While fine-root over-yielding has been shown in the upper soil layers of mixedspecies forests relative to monospecific stands, the consequences of tree diversity on fine-root growth in very deep soil layers is still unknown. Our study aimed to assess the consequences of mixing Acacia
\end{abstract}

Responsible Editor: Michael Luke McCormack.

A. Germon · I. A. Guerrini · J.-P. Laclau

Departamento de Solos e Recursos Ambientais, Universidade Estadual Paulista 'Júlio de Mesquita Filho', Botucatu, SP 18610-300, Brazil

A. Germon · J.-P. Bouillet • Y. Nouvellon · C. Jourdan • J.-P. Laclau

Eco\&Sols, INRA, CIRAD, IRD, Montpellier SupAgro,

University of Montpellier, Montpellier, France

B. Bordron · J.-P. Bouillet • Y. Nouvellon •

J. L. de Moraes Gonçalves · R. R. Paula · J.-P. Laclau

ESALQ, Universidade de São Paulo, Piracicaba, SP 13400-970,

Brazil

J.-P. Bouillet • Y. Nouvellon · C. Jourdan · J.-P. Laclau ( $₫)$

CIRAD, Eco\&Sols, Montpellier, France

e-mail: laclau@cirad.fr

R. R. Paula

Departamento de Ciências Florestais e da Madeira, Universidade Federal do Espírito Santo, Jerônimo Monteiro, ES 29550-00, Brazil mangium and Eucalyptus grandis trees on soil exploration by roots down to the water table at $17 \mathrm{~m}$ depth in a tropical planted forest.

Method Fine roots (diameter $<2 \mathrm{~mm}$ ) were sampled in a randomized block design with three treatments: monospecific stands of Acacia mangium (100A), Eucalyptus grandis (100E), and mixed stands with $50 \%$ of each species (50A50E). Root ingrowth bags were installed at 4 depths (from $0.1 \mathrm{~m}$ to $6 \mathrm{~m}$ ) in the three treatments within three different blocks, to study the fine-root production over 2 periods of 3 months.

Results Down to $17 \mathrm{~m}$ depth, total fine-root biomass was $1127 \mathrm{~g} \mathrm{~m}^{-2}$ in 50A50E, $780 \mathrm{~g} \mathrm{~m}^{-2}$ in $100 \mathrm{~A}$ and $714 \mathrm{~g} \mathrm{~m}^{-2}$ in 100E. Specific root length and specific root area were $110-150 \%$ higher in $50 \mathrm{~A} 50 \mathrm{E}$ than in $100 \mathrm{~A}$ for Acacia mangium trees and 34\% higher in 50A50E than in $100 \mathrm{E}$ for Eucalyptus grandis trees. Ingrowth bags showed that the capacity of fine roots to explore soil patches did not decrease down to a depth of $6 \mathrm{~m}$ for the two species.

Conclusions Belowground interactions between Acacia mangium and Eucalyptus grandis trees greatly increased the exploration of very deep soil layers by fine roots, which is likely to enhance the uptake of soil resources. Mixing tree species might therefore increase the resilience of tropical planted forests through a better exploration of deep soils.

Keywords Plantation - Forest - Deep root - Fine-root density $\cdot$ Root traits · Diversity $\cdot$ Over-yielding $\cdot$ Brazil 


\section{Introduction}

Plantations of fast-growing trees are expanding rapidly to meet the increasing demand for wood products (Keenan et al. 2015). The area covered by planted forests increased from about 168 million ha in 1990 to 278 million ha in 2015, and a large share of the new forest plantations are at sites with in highly weathered tropical soils (Keenan et al. 2015). Fast-growing Eucalyptus plantations cover about 20 million hectares throughout the world (Booth 2013) with about 5.6 million hectares in Brazil (IBA 2016). Eucalyptus plantations provide raw material for pulp and paper, charcoal and firewood in Brazil (Battie-Laclau et al. 2014; Gonçalves et al. 2013). While most of these eucalypt plantations are monospecific, mixed-species stands including nitrogen $(\mathrm{N})$ fixing trees can help to balance the $\mathrm{N}$ budget, improve the $\mathrm{N}$ status of the eucalypts (Forrester et al. 2006; Paula et al. 2015) and, in some situations, increase the total biomass production (Forrester 2014; Richards et al. 2010). Multi-purpose plantations can provide key ecosystem services (Paquette and Messier 2010), and positive relationships between tree diversity and soil fauna, microbial diversity, and soil carbon (C) sequestration are well documented (Blaser et al. 2014; Forrester 2014; Richards et al. 2010). Acacia mangium Wild is another fast-growing tree species widely planted in South-East Asia for pulpwood. Introduction of Acacia mangium trees into commercial eucalypt plantations has been tested recently in Brazil and Congo (Bouillet et al. 2013; Santos et al. 2016; Voigtlaender et al. 2012). Those studies showed that mixed A. mangium and Eucalyptus stands had higher available mineral $\mathrm{N}$ in the soil than monospecific eucalypt stands (Tchichelle et al. 2017; Voigtlaender et al. 2012) and that, in some situations, the total biomass production was higher in mixed stands than monospecific eucalypt stands at the same stocking density (Bouillet et al. 2013; Epron et al. 2013; Santos et al. 2016). While the benefits consequences of a stratified canopy in mixed-species plantations are well documented (Bauhus et al. 2004; Binkley et al. 2013; Le Maire et al. 2013; Williams et al. 2017), soil partitioning between the roots of different tree species in a mixed stand has not been studied to the same extent.

Roots play a key role in forest ecosystems with their mechanical functions of tree anchorage and their physiological function of capturing and transporting the amounts of water and nutrients needed for plant growth
(McCormack and Guo 2014; Pregitzer et al. 2002). Niche complementary among the fine roots of different species is often cited as one of the major processes that can contribute to increasing biomass production in multi-species stands compared to single-species forests (Lehmann 2003). Studies dealing with fine-root density in mixed-species forests are scarce and mainly limited to the upper soil layers. Deep roots, commonly defined as roots growing below $1 \mathrm{~m}$, can provide access to water and nutrient pools that shallow roots cannot reach (Kell 2012). Even though the density of roots is generally low below $1 \mathrm{~m}$ depth compared to the topsoil, they are important in reducing nutrient losses by deep drainage (Laclau et al. 2010) and improving trees' drought tolerance to drought (Christina et al. 2017; McDowell et al. 2008). While the effects of environmental changes on the phenology of aboveground plant components are well documented, belowground processes remain poorly understood (Radville et al. 2016). The lack of information on the influence of interspecific interactions on root exploration at great depth limits our ability to identify the most appropriate sites for multi-species plantations in tropical regions. Fine-root biomass in the $0-2 \mathrm{~m}$ soil layers was found to be $30 \%$ higher in a mixed-species plantation of $E$. grandis and A. mangium trees than in monospecific stands at age 5 years in Brazil (Laclau et al. 2013b). Interaction between the twospecies led to a segregation of the root systems. In mixed stands, A. mangium fine roots were partially excluded from the topsoil in mixture and over-explored the soil layers between the depths of 1 and $2 \mathrm{~m}$ relative to monospecific A. mangium stands (da Silva et al. 2009; Laclau et al. 2013b). However, as far as we are aware, the effects of the inter-specific interaction on fine-root densities at depths $>2 \mathrm{~m}$ have never been studied. Changes in fine-root traits might be a major adaptation of $A$. mangium and E. grandis trees to cope with interspecific interactions in mixed stands. Strong modifications of fine-root morphology have been shown in response to competition through an increase in specific root length (SRL, fine-root length divided by fine-root dry mass) and specific root area (SRA, fine-root area divided by fine-root dry mass) to reduce the cost/benefit ratio of resource capture.

Root growth is controlled by endogenous constraints on carbon availability and environmental factors (Freschet et al. 2017; McCormack et al. 2015). Fineroot production is dependent on soil water content (Canham et al. 2015) and the high plasticity of fine roots 
enables them to explore resource-rich soil patches has been demonstrated (Hodge 2004). The capacity of A. mangium and E. grandis roots to explore soil patches might therefore vary depending on the season and the depth in the soil. Although ingrowth bags have been commonly used to estimate fine-root production in forest ecosystems (Brunner et al. 2013), the root-free soil in the ingrowth bags can be richer in nutrients and water than the surrounding soil (without water and nutrient uptake in the first weeks after installation), which can lead to overestimates of the fine-root production and length in these soil patches relative to the surrounding soil (Bauhus and Messier 1999; Jourdan et al. 2008).

Our study aimed to assess the consequences of mixing Acacia mangium and Eucalyptus grandis trees on fine-root growth down very deep profiles in highly weathered tropical soils. We hypothesized that the interaction between Acacia mangium and Eucalyptus grandis trees in mixed stands modified root growth relative to monospecific stands, resulting in i) fine-root over-yielding in all the soil layers down to the water table at a depth of $17 \mathrm{~m}$, ii) modification of common fine-root traits (diameter, SRL, SRA) for the two species making it possible to increase the area of soil resource capture per gram of $\mathrm{C}$ invested in fine roots, and iii) a higher capacity of the tree roots to explore soil patches in the topsoil than in very deep soil layers reflecting the decrease in fine-root density with depth.

\section{Materials and methods}

Study site

The study was carried out at the Itatinga experimental station of University of São Paulo, Brazil $\left(23^{\circ} 02^{\prime}\right.$ S., $48^{\circ} 38^{\prime}$ W., $860 \mathrm{~m}$ a.s.1.). This region has a humid subtropical climate (Cfa according to the Köppen classification) with an average annual rainfall of $1390 \mathrm{~mm}$ (mean from 1990 to 2010), a mean relative humidity of $77 \%$ and a mean annual temperature of $19{ }^{\circ} \mathrm{C}$ with a cold and dry season from June to September. The soils are Ferralsols (FAO classification) developed on Cretaceous sandstone with a water table at a depth of $17 \mathrm{~m}$ (Pradier et al. 2017). Sand content was around $85 \%$ in the topsoil and 75-80\% between $1 \mathrm{~m}$ and $15 \mathrm{~m}$ depth (Maquere 2008). Soil $\mathrm{pH}_{\mathrm{H} 2 \mathrm{O}}$ was approximately $5.5 \mathrm{in}$ the upper $3 \mathrm{~m}$, cation exchange capacity decreased from $18 \mathrm{mmol}_{\mathrm{c}} \mathrm{kg}^{-1}$ in the $0-5 \mathrm{~cm}$ soil layer to $2 \mathrm{mmol}_{\mathrm{c}} \mathrm{kg}^{-1}$ in the 2-3 m layer, and exchangeable cation contents dropped below a depth of $5 \mathrm{~cm}$. Full details were given in a previous study (Laclau et al. 2013b).

\section{Experimental layout}

The trial was a complete randomized block design with 7 treatments and 4 blocks set up in May 2003 in a site which had been a Eucalyptus grandis plantation from 1998 to 2002 and previously a Eucalyptus saligna Sm. coppice from 1940 to 1998 . The experimental layout was described in detail by Laclau et al. (2008) and Le Maire et al. (2013). There were plots with A. mangium monoculture, E. grandis monoculture and mixed plantations of $A$. mangium and E. grandis within each block. Each plot was $30 \mathrm{~m} \times 30 \mathrm{~m}$ with two buffer rows. The seedlings were planted at a density of 1111 trees ha ${ }^{-1}$ ( $3 \mathrm{~m} \times 3 \mathrm{~m}$ spacing). The trees were harvested at age 6 years (in May 2009) and only the harvested boles were removed from the plots. Harvest residues were spread uniformly over each plot and A. mangium and E. grandis seedlings were re-planted in November 2009 in the same planting rows of the same plots, at $50 \mathrm{~cm}$ from the stumps of the previous rotation.

Our study was carried out 4 years after replanting in 3 treatments within 3 blocks: A. mangium and E. grandis monospecific stands (100A and $100 \mathrm{E}$, respectively) and mixed stands with $50 \%$ of each species (50A50E). In the mixed stand, the two species were planted alternately in the row and offset adjacent rows (555 trees ha ${ }^{-1}$ per species). The Acacia mangium seedlings were inoculated with rhizobia strains selected by EMBRAPA (Agrobiology, Rio de Janeiro) for their $\mathrm{N}_{2}$ fixation capacities. The same amounts of $\mathrm{P}, \mathrm{K}, \mathrm{Ca}, \mathrm{Mg}$, and micronutrients were applied the first 18 months after planting in all the plots (no $\mathrm{N}$ fertilization). Destructive sampling at age 3.3 years showed that mixing the two species did not lead to higher aboveground biomass in $50 \mathrm{~A} 50 \mathrm{E}$ than the average of the two monocultures. Tree height was about $8 \mathrm{~m}$ higher for $E$. grandis than for A. mangium (Table 1).

\section{Root sampling}

Fine roots (diameter $<2 \mathrm{~mm}$ ) were sampled down to a depth of $17 \mathrm{~m}$ in the three treatments $(100 \mathrm{~A}, 100 \mathrm{E}$ and 50A50E; Fig. 1) within the three blocks. Three replicates of soil samples were collected at mid distance between 4 adjacent trees (Fig. 1) in each plot down to 
Table 1 Main characteristics of the stands at 39 months (mean and standard deviation between blocks, $n=3$ )

\begin{tabular}{|c|c|c|c|c|c|}
\hline & \multirow{2}{*}{$\begin{array}{l}100 \mathrm{~A} \\
\text { A. mangium }\end{array}$} & \multirow{2}{*}{$\begin{array}{l}100 \mathrm{E} \\
\text { E. grandis }\end{array}$} & \multicolumn{3}{|l|}{$50 \mathrm{~A}: 50 \mathrm{E}$} \\
\hline & & & A. mangium & E. grandis & Total \\
\hline Stocking density (trees $\mathrm{ha}^{-1}$ ) & $988 \pm 18$ & $1111 \pm 0$ & $535 \pm 21$ & $556 \pm 0$ & $1091 \pm 15$ \\
\hline Stand basal area $\left(\mathrm{m}^{2} \mathrm{ha}^{-1}\right)$ & $15.3 \pm 0.4 \mathrm{~B} \mathrm{a}$ & $16.6 \pm 0.4 \mathrm{~A} \mathrm{a}$ & $7.1 \pm 0.8 \mathrm{~b}$ & $9.3 \pm 0.6 \mathrm{~b}$ & $16.4 \pm 0.2 \mathrm{~A}$ \\
\hline Tree height (m) & $9.3 \pm 0.2 \mathrm{C} \mathrm{a}$ & $17.8 \pm 0.2 \mathrm{~A} \mathrm{a}$ & $9.5 \pm 0.3 \mathrm{a}$ & $16.8 \pm 0.1 \mathrm{~b}$ & $13.1 \pm 0.2 \mathrm{~B}$ \\
\hline \multicolumn{6}{|l|}{ Biomass $\left(\mathrm{kg} \mathrm{m}^{-2}\right)$ : } \\
\hline Leaves & $0.66 \pm 0.02 \mathrm{~A} \mathrm{a}$ & $0.58 \pm 0.02 \mathrm{~B} \mathrm{a}$ & $0.22 \pm 0.03 \mathrm{~b}$ & $0.46 \pm 0.03 \mathrm{~b}$ & $0.67 \pm 0.01 \mathrm{~A}$ \\
\hline Branches & $0.83 \pm 0.02 \mathrm{~A} \mathrm{a}$ & $0.81 \pm 0.02 \mathrm{~A} \mathrm{a}$ & $0.31 \pm 0.04 \mathrm{~b}$ & $0.57 \pm 0.07 \mathrm{~b}$ & $0.88 \pm 0.03 \mathrm{~A}$ \\
\hline Bark & $0.53 \pm 0.01 \mathrm{C} \mathrm{a}$ & $0.67 \pm 0.02 \mathrm{~A} \mathrm{a}$ & $0.18 \pm 0.02 b$ & $0.43 \pm 0.02 \mathrm{~b}$ & $0.62 \pm 0.00 \mathrm{~B}$ \\
\hline Wood & $1.99 \pm 0.05 \mathrm{C} \mathrm{a}$ & $4.96 \pm 0.13 \mathrm{~A} \mathrm{a}$ & $0.80 \pm 0.09 \mathrm{~b}$ & $2.29 \pm 0.12 b$ & $3.09 \pm 0.03 \mathrm{~B}$ \\
\hline Aboveground biomass & $4.01 \pm 0.09 \mathrm{C} \mathrm{a}$ & $7.03 \pm 0.19 \mathrm{~A} \mathrm{a}$ & $1.51 \pm 0.17 b$ & $3.75 \pm 0.24 b$ & $5.26 \pm 0.07 \mathrm{~B}$ \\
\hline
\end{tabular}

Different uppercase letters indicate significant differences between treatments, and different lowercase letters indicate significant differences between the monospecific stands and the mixed stands for each species $(p<0.05)$. The methods used to estimate the aboveground biomass are described in Nouvellon et al. (2012)

a depth of $6 \mathrm{~m}$ and one replicate per plot between the depths of $6 \mathrm{~m}$ and $17 \mathrm{~m}$ (total of 9 samples per treatment in each soil layer down to $6 \mathrm{~m}$ depth and 3 samples between the depths of $6 \mathrm{~m}$ and $17 \mathrm{~m}$ ). At each sampling position, soil layers $0-0.5,0.5-1.0,1.0-1.5,1.5-2.0$, $2.0-3.0,3.0-4.0,4.0-5.0,5.0-6.0 \mathrm{~m}$ were collected by digging a square hole of approximately $15 \mathrm{~cm} \times 15 \mathrm{~cm}$ area at the soil surface (an operator used a tool designed to dig very deep holes, called 'cavadeira' in Brazil). Only the soil mass sampled was measured accurately, the volume of the soil samples extracted using the 'cavadeira' tool could not be measured and was estimated by multiplying the soil dry mass of the samples by the bulk density in each layer (see below). About $15 \mathrm{~kg}$ and $30 \mathrm{~kg}$ of soil were collected at each sampling position for layers $50 \mathrm{~cm}$ and $100 \mathrm{~cm}$ thick, respectively. Fresh soil mass was measured in the field $( \pm 10 \mathrm{~g})$ and all the fine roots easily visible were collected. The soil was then homogenized and a sub-sample of approximately $0.5 \mathrm{~kg}$ in the $0-50 \mathrm{~cm}$ soil layer, $1 \mathrm{~kg}$ in soil layers $0.5-$ $1.0,1.0-1.5,1.5-2.0,2.0-3.0,3.0-4.0 \mathrm{~m}$, and $2 \mathrm{~kg}$ in soil layers $4.0-5.0$ and $5.0-6.0 \mathrm{~m}$ was taken to separate short lengths of root and small diameter fine roots in the laboratory. Each sub-sample was weighed in the laboratory and the soil water content was measured (by drying $5 \mathrm{~g}$ of soil at $105^{\circ} \mathrm{C}$ for $72 \mathrm{~h}$ ).

Below a depth of $6 \mathrm{~m}$, soil cores were taken every $1 \mathrm{~m}$ depth using a cylindrical auger with an inner diameter of $9 \mathrm{~cm}$ and a length of $30 \mathrm{~cm}$. We used the same methodology as Christina et al. (2011) to avoid contamination of the soil samples collected at depth by roots from the upper layers. Only soil blocks from the inner

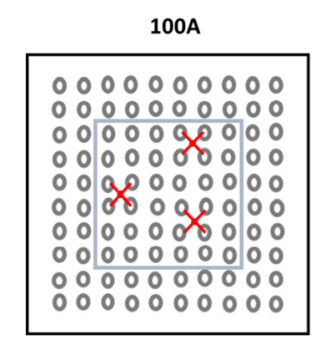

Fig. 1 Layout of the three treatments studied: Acacia mangium and Eucalyptus grandis monospecific stands (100A and 100E, respectively) and a mixed stands with $50 \%$ of each species (50A50E). A. mangium trees are represented by grey circles and E. grandis trees by black triangles. Each inner plot (excluding two buffer rows) is delimited by a grey square. Three replicates
$100 \mathrm{E}$

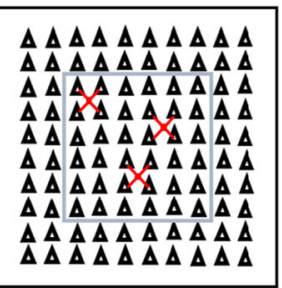

50A50E

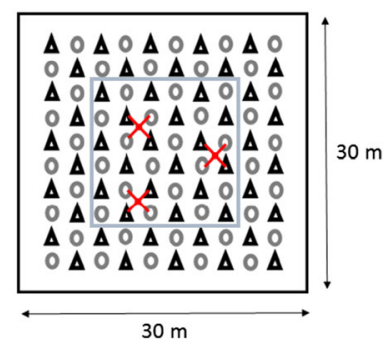

samples (position indicated by a red cross) of soil cores were collected at mid distance between 4 adjacent trees in each plot down to a depth of $6 \mathrm{~m}$ and one sample per plot between the depths of $6 \mathrm{~m}$ and $17 \mathrm{~m}$. Only one block is presented. A complete scheme of the trial is presented on Fig. 1 in Le Maire et al. (2013) 
part of the auger were collected and all fragmented soil pieces likely to come from upper soil layers were systematically discarded. All the soil collected from each layer was put in plastic bag, identified and stored at $4{ }^{\circ} \mathrm{C}$ until processing (within 2 months after sampling).

All the fine roots in the samples were washed free of soil with tap water using sieves (with mesh sizes from 0.50 to $1.19 \mathrm{~mm}$ ) and all the living roots with a length $>1 \mathrm{~cm}$ were separated carefully by hand. Dead roots separated by sight, touch and flotation, if required were discarded. Living roots were selected by various criteria such as living stele, bright color and elasticity. The color of the roots and the ramification pattern were good indications of the species to which they belonged. Reference roots sampled in monospecific stands were used to facilitate the identification of each species for roots collected in the 50A50E treatment. E. grandis fine roots were more branched and were darker than A. mangium fine roots. A sub-sample (10\% of the weight of each soil sample) was used to estimate the mass of extremely fine roots (pieces of roots less than $1 \mathrm{~cm}$ in length). Extremely fine roots were separated carefully by hand in a white bucket filled with tap water. The mass of short root fragments (less than $1 \mathrm{~cm}$ in length) measured in $10 \%$ of the soil sample mass was multiplied by 10 to estimate the mass of those root fragments in the whole soil sample. All living fine roots with a length $>1 \mathrm{~cm}$ separated from each soil sample were scanned (400 dpi resolution). Nodules were scanned with the fine roots when they were present. Root lengths and areas were estimated in each sample using WinRHIZO Version Pro V.2009c software (Regent Instruments, QC, Canada). Fine roots were dried for $72 \mathrm{~h}$ at $65{ }^{\circ} \mathrm{C}$ and weighed $( \pm 0.1 \mathrm{mg})$ to estimate specific root length (SRL, length of scanned roots divided by their dry mass mass, expressed in $\mathrm{m} \mathrm{g}^{-1}$ ) and specific root area (SRA, surface area of scanned roots divided by their dry mass, expressed in $\mathrm{cm}^{2} \mathrm{~g}^{-1}$ ) in each soil sample. Fine-root mass density in each soil sample was calculated taking account of the soil dry mass used for the separation of the fine roots in the field and in the laboratory. Soil bulk densities measured in a pit down to a depth of $17 \mathrm{~m}$ in each treatment were used to convert fine-root mass densities expressed in $\mathrm{g}$ of root per $\mathrm{kg}$ of soil to $\mathrm{g}$ of root per $\mathrm{dm}^{3}$ of soil in each layer (the same method was used from the soil surface down to a depth of $17 \mathrm{~m}$ ). Fine-root biomasses were computed in each soil layer multiplying the soil layer volume $\left(\mathrm{dm}^{3}\right)$ by the mean fine-root density. Total root length and total root area in each soil sample were calculated by multiplying the total root dry mass by SRL and SRA, respectively. Root area index (RAI, surface area of fine roots divided by sampled soil area, expressed in $\mathrm{m}^{2} \mathrm{~m}^{-2}$ ) and root length index (RLI, length of scanned roots divided by sampled soil area, expressed in $\mathrm{km} \mathrm{m}^{-2}$ ) (Jackson et al. 1997) were calculated for each soil layer in each treatment.

\section{Root ingrowth bags}

Fine-root production over two periods of 3 months were studied using cylindrical ingrowth bags constructed from stainless steel with a mesh size of $2 \mathrm{~mm}$, a diameter of $9 \mathrm{~cm}$ and a height of $35 \mathrm{~cm}$. The 3 -month periods of root regrowth were selected for very fast eucalypt fine root growth, with maximum ingrowth core colonization after 2 months, following a previous study at the same study site (see Fig. 5 in Jourdan et al. (2008)). Three replicates of root ingrowth bags were installed at 4 depths (soil layers $0.10-0.45 \mathrm{~m}, 1.00-1.35 \mathrm{~m}, 3.00$ $3.35 \mathrm{~m}$ and $6.00-6.35 \mathrm{~m}$ ) in the same plots used to study the fine-root densities (three treatments in three blocks) giving a total of 108 ingrowth bags for each period of 3 months. Holes (diameter $15 \mathrm{~cm}$ ) were made manually (using the 'cavadeira' tool) to install the mesh bags at each depth $(0.45 \mathrm{~m}, 1.35 \mathrm{~m}, 3.35 \mathrm{~m}$ or $6.35 \mathrm{~m})$. The bags were filled with the soil from the corresponding soil layer, and moistened to field capacity after removing all the roots. The flexibility of the bags allowed a good contact with the surrounding soil. PVC pipes (diameter of $0.15 \mathrm{~m}$, length of $0.1 \mathrm{~m}, 1 \mathrm{~m}, 3 \mathrm{~m}$ or $6 \mathrm{~m}$ depending on the depth of the bag) were placed into the holes above the ingrowth bags to make possible to retrieve of each bag from the surface using a nylon cord attached (Appendix Fig. 7). A plastic bag (with a nylon cord attached) filled with about $2 \mathrm{~kg}$ of soil was placed between the root ingrowth bag and the bottom of the PVC tube to avoid air diffusion from inside the PVC tube to the ingrowth bags that could affect fine-root growth. The top of each PVC tube was hermetically sealed. The mesh size of $2 \mathrm{~mm}$ allowed fine-root growth. After a period of 3 months, the bags were carefully retrieved. We set up additional ingrowth cores at the depths of $0.1 \mathrm{~m}$ and $1 \mathrm{~m}$ in the buffer rows of our experiment to check whether fine-roots were torn out when we pulled up the ingrowth cores 3 months after their installation. Destructive soil sampling close to the ingrowth cores showed that most of the fine roots of the 
two species were sheared by the stainless-steel mesh when the core was retrieved and the biomass of fine roots not recovered inside the soil core was negligible. Two periods were studied: from July to September 2013 (winter) and October to December 2013 (spring). Just after the bags were retrieve, new bags were inserted at the same place to study the following 3-month period. All the fine roots in the samples were washed free of soil with tap water using sieves and separated carefully by hand. The roots of the two species were distinguished in the 50A50E treatment as described above.

\section{Statistical analyses}

Two-way analyses of variance (ANOVAs) were used to assess the effects of treatments $(100 \mathrm{~A}, 100 \mathrm{E}$ and $50 \mathrm{~A} 50 \mathrm{E})$ and blocks on fine-root densities (FRD), specific root length (SRL), specific root area (SRA), fineroot diameter, root length index (RLI) and root area index (RAI) for individual soil layers. Individual root biomass measurements within a given soil layer were considered independent since the sampling positions were located near different trees in each plot. We used linear mixed-effects models to test the effects of soil depth, treatment, and the interaction between depth and treatment (as fixed effect) on FRD, SRL, SRA, fine-root diameter, RLI and RAI for the whole soil profile. Blocks were considered as random effects and residues were modeled by a first-order autoregressive correlation model to account for the correlations between soil depths. A Shapiro-Wilk test was performed on the data before modeling and log-transformation was used when the residuals did not follow a normal distribution. In addition, two-way ANOVAs were carried out for each soil layer to compare the FRD of each tree species (E. grandis or A. mangium) in the mixed stands with $50 \%$ of the FRD in the monoculture of the same species in the same block. The effects of treatments and depth on FRD in the ingrowth bags were tested using two-way ANOVAs for each 3-month period studied. Post-hoc differences were analysed using Tukey's post-hoc Honest Significant Difference (HSD) to determine which means differed significantly between treatments. All calculations and analyses were performed using the $\mathrm{R}$ software version 3.2.2 (Team R 2013) and the level of significance was 0.05 . Linear mixed-effects models used the lmerTest package (Kuznetsova et al. 2015). For the graphical representations, the mean values and standard errors were calculated from all the replicates ( $n=9$ down to a depth of $6 \mathrm{~m}$ and $n=3$ below).

\section{Results}

Fine-root over-yielding

Auger sampling down to the root front (maximum depth of root observation) showed that trees in 50A50E, 100A and $100 \mathrm{E}$ exhibited a similar pattern of deep rooting. Fine-roots densities dropped sharply from the $0-0.5 \mathrm{~m}$ layer to the $0.5-1.0 \mathrm{~m}$ layer and decreased gradually down to a depth of $12 \mathrm{~m}$ in 100A and down to the water table at a depth of $17 \mathrm{~m}$ in 100E and 50A50E (Fig. 2). Mixing E. grandis and A. mangium led to fine-root overyielding. Fine-root biomass in 50A50E (1127 $\left.\mathrm{g} \mathrm{m}^{-2}\right)$ was $44 \%$ higher than in 100A $\left(780 \mathrm{~g} \mathrm{~m}^{-2}\right)$ and $58 \%$ higher than in 100E $\left(714 \mathrm{~g} \mathrm{~m}^{-2}\right)$ (Table 2). Fine-root densities were $20-100 \%$ higher in 50A50E than in 100E and $100 \mathrm{~A}$ in most of the soil layers and were at least twice as high in 50A50E as in 100A in soil layers 1.5$2 \mathrm{~m}, 2-3 \mathrm{~m}, 3-4 \mathrm{~m}$, and at depths $>8 \mathrm{~m}$. Low fine-root densities at depths $>8 \mathrm{~m}$ in $100 \mathrm{~A}$ were consistent with higher soil water contents in $100 \mathrm{~A}$ than in $100 \mathrm{E}$ and 50A50E (Fig. 2).

Fine-root distribution of each species in monospecific stands vs mixed stands

Intra- and inter-specific interactions strongly influenced the distribution of $A$. mangium and E. grandis fine roots, irrespective of the soil layer (Table 4). The total fine-root biomass of A. mangium trees in 50A50E was $54 \%$ of the biomass in $100 \mathrm{~A}$, whereas the planting density was only $50 \%$ of that in $100 \mathrm{~A}$, with the slightly lower exploration of the 0-2 $\mathrm{m}$ soil layer than in 100A offset by a higher exploration of very deep soil layers (Fig. 3). E. grandis fine-root biomass was only $2 \%$ lower in $50 \mathrm{~A} 50 \mathrm{E}$ than in $100 \mathrm{E}$, despite the stocking density being $50 \%$ lower (Fig. 3). E. grandis fine-root biomass in $50 \mathrm{~A} 50 \mathrm{E}$ was significantly higher than $50 \%$ of that in $100 \mathrm{E}$ in all layers except 1-2 $\mathrm{m}$ and 4-6 $\mathrm{m}$. Even though the fineroot biomass was low between the depths of 9 and $12 \mathrm{~m}$ in all the treatments (about $6 \%$ of the total fine-root biomass), A. mangium and E. grandis fine-root biomasses at this depth were 2-3 times higher in 50A50E than in the monospecific stands where the stocking density of each species was twice as high (Fig. 3). 


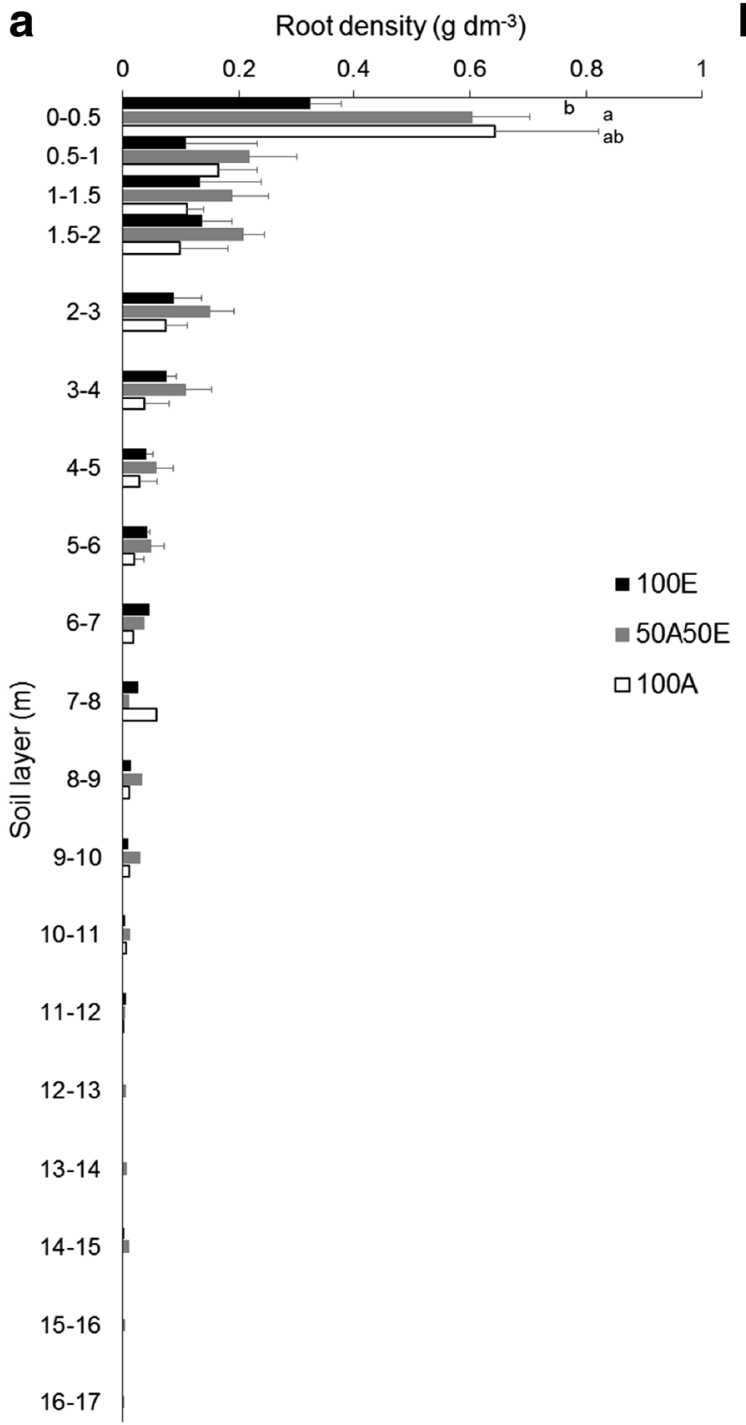

Fig. 2 Mean fine-root densities (a) and gravimetric water content (b) down to the root front in treatments 100E (filled black bars), 100A (open bars) and 50A50E (filled grey bars). Standard errors between blocks are given down to a depth of $6 \mathrm{~m}(\mathrm{n}=3)$. Different b Gravimetric water content (\%)

$\begin{array}{lllll}0 & 4 & 8 & 12 & 16\end{array}$

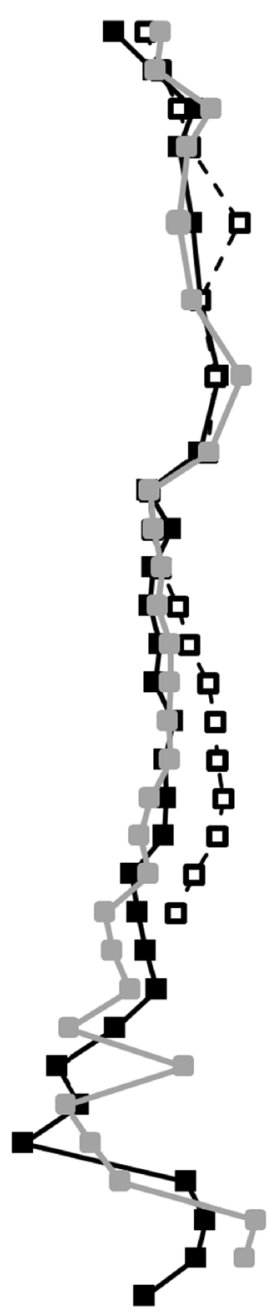

letters indicate significant differences between treatments within each individual soil layer down to $6 \mathrm{~m}$ depth $(\mathrm{p}<0.05$, only significant in the upper soil layer)

Table 2 Total fine-root biomass down to a depth of $17 \mathrm{~m}$ and mean specific root length (SRL), mean specific root area (SRA) and mean fine-root diameter down to a depth of $6 \mathrm{~m}$ in $100 \mathrm{~A}, 100 \mathrm{E}$ and $50 \mathrm{~A} 50 \mathrm{E}$ at 4 years of age

\begin{tabular}{|c|c|c|c|c|c|}
\hline & \multirow{2}{*}{$\begin{array}{l}100 \mathrm{~A} \\
\text { A. mangium }\end{array}$} & \multirow{2}{*}{$\begin{array}{l}100 \mathrm{E} \\
\text { E. grandis }\end{array}$} & \multicolumn{3}{|l|}{$50 \mathrm{~A} 50 \mathrm{E}$} \\
\hline & & & A. mangium & E. grandis & Total \\
\hline Fine-root biomass $\left(\mathrm{g} \mathrm{m}^{-2}\right)$ & $779.68 \mathrm{~B}$ & $714.19 \mathrm{~B}$ & 421.94 & 696.93 & $1127.01 \mathrm{~A}$ \\
\hline Specific root length $\left(\mathrm{m} \mathrm{g}^{-1}\right)$ & $17.98 \mathrm{~b}$ & $20.53 \mathrm{~b}$ & $45.63 \mathrm{a}$ & $28.11 \mathrm{a}$ & \\
\hline Specific root area $\left(\mathrm{cm}^{2} \mathrm{~g}^{-1}\right)$ & $268.36 \mathrm{~b}$ & $253.57 \mathrm{~b}$ & $584.11 \mathrm{a}$ & $338.55 \mathrm{a}$ & \\
\hline Diameter (mm) & $0.53 \mathrm{~b}$ & $0.47 \mathrm{a}$ & $0.48 \mathrm{a}$ & $0.47 \mathrm{a}$ & \\
\hline
\end{tabular}

Different uppercase letters indicate significant differences between treatments, and different lowercase letters indicate significant differences between the monospecific stands and the mixed stands for each species $(p<0.05)$ 
Fig. 3 Percentages of fine-root biomass in each soil layer in $50 \mathrm{~A} 50 \mathrm{E}$ relative to the fine-root biomass in the single-species stands. The dotted line indicates the $50 \%$ reference for Acacia mangium roots (open bars with standard errors) and Eucalyptus grandis roots (solid bars with standard errors), if root development was similar to the monoculture, for a $50 \%$ tree stocking density for each species. Standard error bars are shown. Asterisks * denotes a significant difference $(\mathrm{p}<0.05)$ between the root biomass of a particular species in 50A50E and $50 \%$ of the biomass in the monoculture of the same species

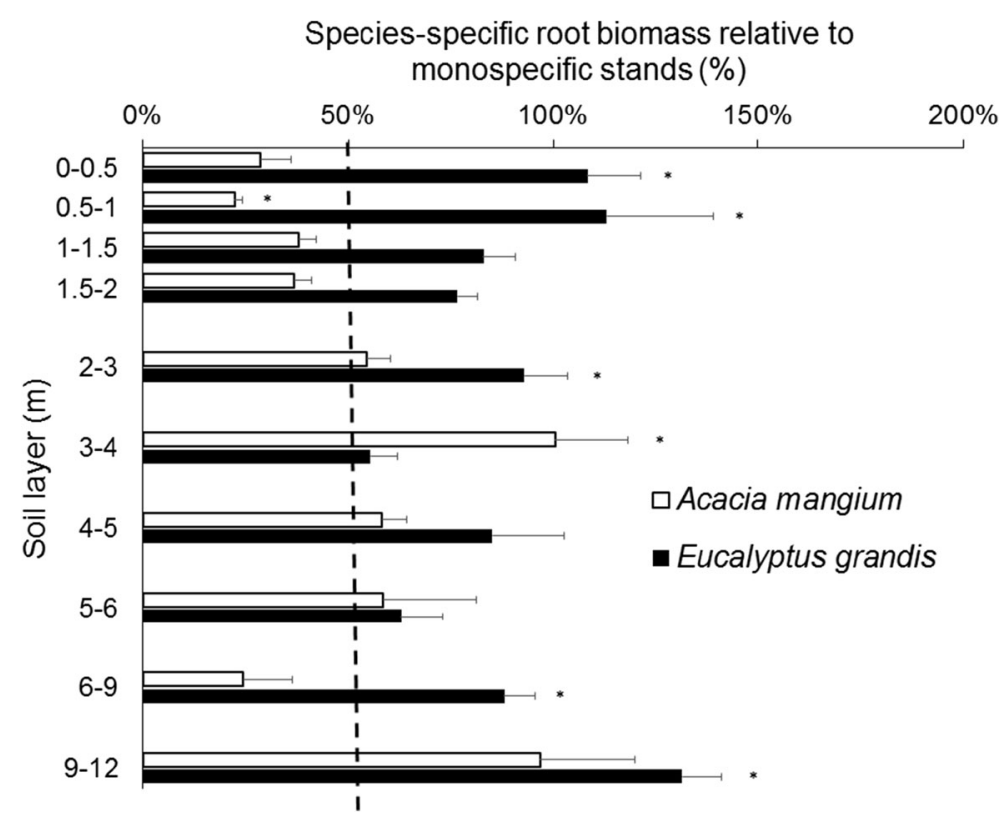

Fine-root traits of each species in monospecific stands vs mixed stands

Total fine-root length index (RLI) was $30 \mathrm{~km} \mathrm{~m}^{-2}$ in $50 \mathrm{~A} 50 \mathrm{E}$ and was double that in $100 \mathrm{~A}\left(13 \mathrm{~km} \mathrm{~m}^{-2}\right)$ and in 100E $\left(15 \mathrm{~km} \mathrm{~m}^{-2}\right)$ (Fig. 5). The RLIs in soil layers $0-1 \mathrm{~m}, 2-4 \mathrm{~m}, 4-6 \mathrm{~m}$ and 9-17 m were significantly higher in 50A50E than in $100 \mathrm{~A}$ and $100 \mathrm{E}$. Total fine-root area index (RAI) was $28 \mathrm{~m}^{2} \mathrm{~m}^{-2}$ in $50 \mathrm{~A} 50 \mathrm{E}$ and was significantly higher than in $100 \mathrm{~A}$ $\left(20 \mathrm{~m}^{2} \mathrm{~m}^{-2}\right)$ and 100E $\left(19 \mathrm{~m}^{2} \mathrm{~m}^{-2}\right)$ (Fig. 5). While about $50 \%$ of the total RAI was found in the top $1 \mathrm{~m}$ soil layer in 50A50E $\left(12.7 \mathrm{~m}^{2} \mathrm{~m}^{-2}\right)$ and 100A $\left(8.2 \mathrm{~m}^{2} \mathrm{~m}^{-2}\right)$, only $22 \%$ of the total RAI was found in the top $1 \mathrm{~m}$ in $100 \mathrm{E}\left(4.2 \mathrm{~m}^{2} \mathrm{~m}^{-2}\right)$ and a high proportion of the total RAI was in the $1-2 \mathrm{~m}$ soil layer $\left(5.8 \mathrm{~m}^{2} \mathrm{~m}^{-2}\right)$. The RAI at depths $>4 \mathrm{~m}$ was about $6 \mathrm{~m}^{2} \mathrm{~m}^{-2}$, irrespective of the treatment.

Table $3 P$ values of linear mixed models for specific root length (SRL), specific root area (SRA) and root diameter applied to the whole soil profile between $100 \mathrm{~A}$ and $50 \mathrm{~A} 50 \mathrm{E}$ for A. mangium
While specific root length (SRL) and specific root area (SRA) were significantly higher in 50A50E than in the monospecific stands, the mean fine-root diameter was significantly higher in $100 \mathrm{~A}$ than in $100 \mathrm{E}$ and 50A50E (Tables 2 and 3). Down to a depth of $6 \mathrm{~m}$, mean values of SRL were 18.0, 20.5 and $34.9 \mathrm{~m} \mathrm{~g}^{-1}$ in $100 \mathrm{~A}, 100 \mathrm{E}$ and $50 \mathrm{~A} 50 \mathrm{E}$, respectively, and the mean values of SRA were 268, 254 and $433 \mathrm{~cm}^{2} \mathrm{~g}^{-1}$ (Table 2). Mean fine-root diameter was $0.53 \mathrm{~mm}$ in $100 \mathrm{~A}$, and $0.47 \mathrm{~mm}$ in $100 \mathrm{E}$ and 50A50E. Depth had little effect on SRL, SRA and fine-root diameter for either species, irrespective of the treatment (Fig. 4).

Mixing A. mangium and E. grandis trees led to a significant increase in SRL and SRA for the roots of both species (Tables 2, 3, and 4) while the mean fineroot diameter was significantly lower in mixed stands than in monoculture for $A$. mangium but not for E. grandis. SRL and SRA of A. mangium roots were 2

roots and between $100 \mathrm{E}$ and $50 \mathrm{~A} 50 \mathrm{E}$ E. grandis roots as a function of treatment, soil depth and the interactions between factors

\begin{tabular}{|c|c|c|c|c|c|c|}
\hline & \multicolumn{2}{|l|}{ SRL } & \multicolumn{2}{|l|}{ SRA } & \multicolumn{2}{|l|}{ Diameter } \\
\hline & A. mangium & E. grandis & A. mangium & E. grandis & A. mangium & E. grandis \\
\hline Treatment & $<0.0001$ & 0.0029 & $<0.0001$ & 0.0024 & $<0.0001$ & 0.889 \\
\hline Depth & 0.3230 & 0.3238 & 0.675 & 0.6732 & 0.419 & 0.7353 \\
\hline Depth $x$ Treatment & 0.3854 & 0.5431 & 0.5988 & 0.8325 & 0.9029 & 0.9879 \\
\hline
\end{tabular}


a

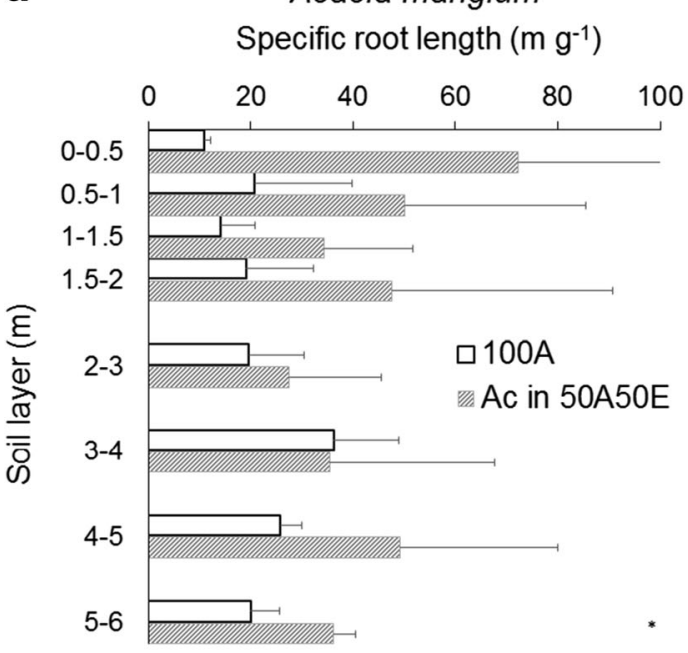

Acacia mangium
Specific fine root area $\left(\mathrm{cm}^{2} \mathrm{~g}^{-1}\right)$

b

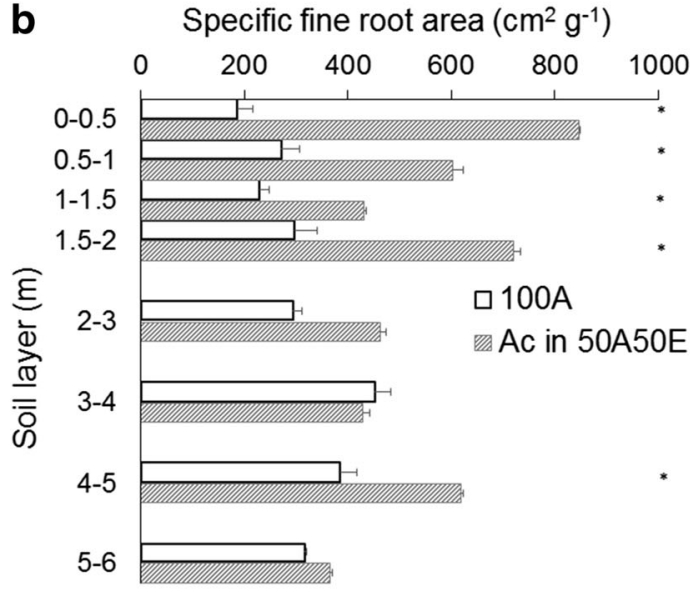

C

Root diameter ( $\mathrm{mm}$ )

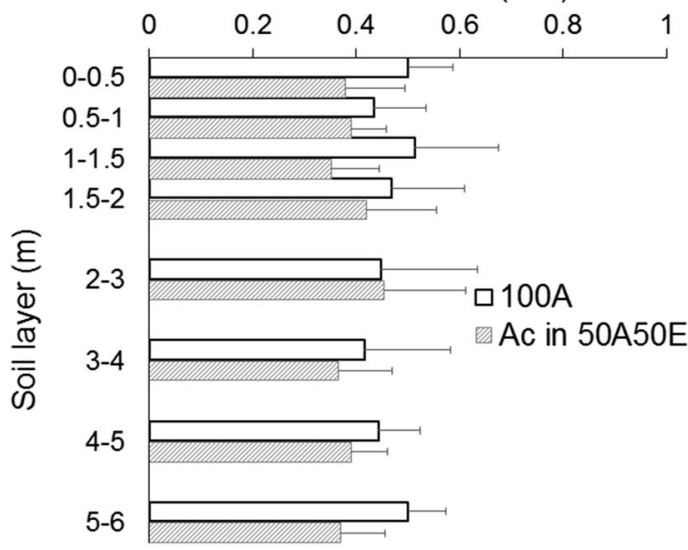

Fig. 4 Specific root length (a), specific root area (b) and mean fine-root diameter (c) in each soil layer for Acacia mangium (left) and Eucalyptus grandis (right) in monospecific stands and in

\section{Eucalyptus grandis}

Specific root length $\left(\mathrm{m} \mathrm{g}^{-1}\right)$

$0-0.5$

$0.5-1$

$1-1.5$

$1.5-2$

$2-3$
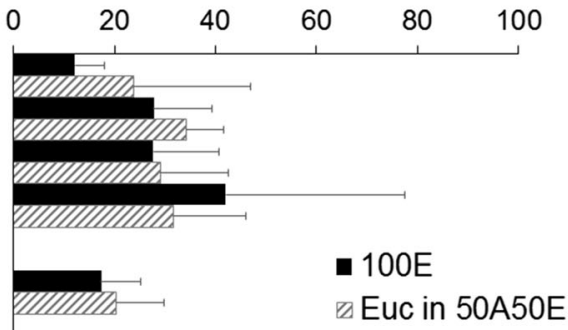

3-4

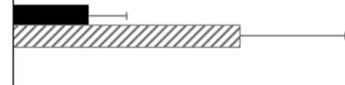

4-5

5-6 $\square$ Euc in 50A50E

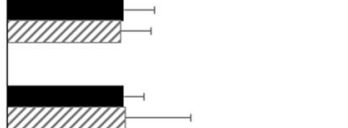

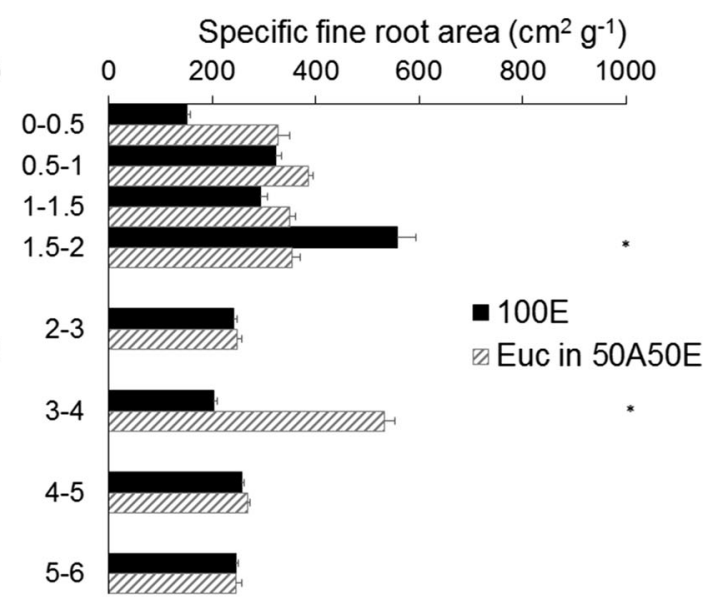

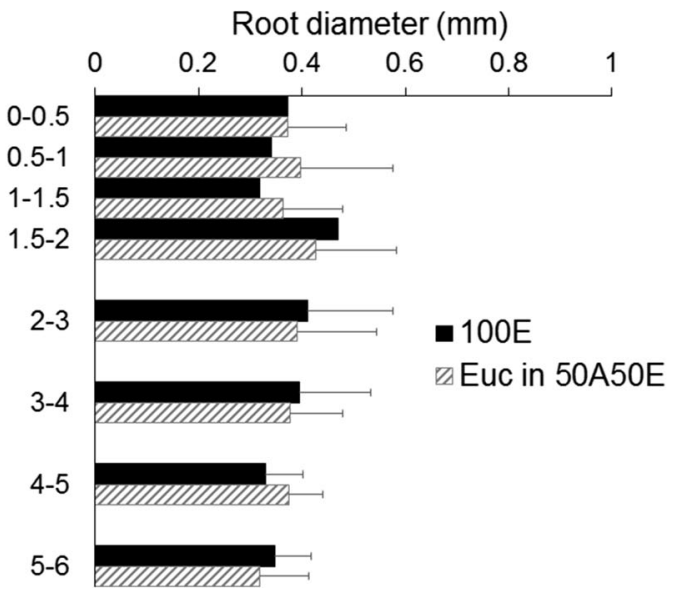

50A50E. Standard errors between blocks are indicated $(n=3)$. Asterisks * denotes a significant difference $(\mathrm{p}<0.05)$ between 50A:50E and the monoculture 
Table 4 Fine-root biomass $\left(\mathrm{g} \mathrm{m}^{-2}\right)$ in 100A, 100E and 50A50E

\begin{tabular}{|c|c|c|c|c|c|}
\hline \multirow[t]{2}{*}{ Soil layer (m) } & \multirow{2}{*}{$\begin{array}{l}100 \mathrm{~A} \\
\text { A. mangium }\end{array}$} & \multirow{2}{*}{$\begin{array}{l}100 \mathrm{E} \\
\text { E. grandis }\end{array}$} & \multicolumn{3}{|l|}{$50 \mathrm{~A} 50 \mathrm{E}$} \\
\hline & & & A. mangium & E. grandis & Total \\
\hline $0-0.5$ & $321(41 \%) \mathrm{A}$ & $161(23 \%) \mathrm{B}$ & $126(30 \%)$ & $173(25 \%)$ & $302(27 \%) \mathrm{A}$ \\
\hline $0.5-1$ & $82(11 \%) \mathrm{AB}$ & $54(8 \%) \mathrm{B}$ & $33(8 \%)$ & $75(11 \%)$ & $109(10 \%) \mathrm{A}$ \\
\hline $1-1.5$ & $55(7 \%) \mathrm{B}$ & $67(9 \%) \mathrm{B}$ & $33(8 \%)$ & $60(9 \%)$ & $94(8 \%) \mathrm{A}$ \\
\hline $1.5-2$ & $49(6 \%) \mathrm{B}$ & $68(10 \%) \mathrm{B}$ & $35(8 \%)$ & $68(10 \%)$ & $104(9 \%) \mathrm{A}$ \\
\hline $2-3$ & $74(9 \%) \mathrm{B}$ & $89(12 \%) \mathrm{B}$ & $58(14 \%)$ & $91(13 \%)$ & $151(13 \%) \mathrm{A}$ \\
\hline $3-4$ & $38(5 \%) \mathrm{C}$ & $76(11 \%) \mathrm{B}$ & $45(11 \%)$ & $62(9 \%)$ & $108(10 \%) \mathrm{A}$ \\
\hline $4-5$ & $29(4 \%) \mathrm{A}$ & $41(6 \%) \mathrm{A}$ & $23(6 \%)$ & $34(5 \%)$ & $58(5 \%) \mathrm{A}$ \\
\hline $5-6$ & $20(3 \%) \mathrm{B}$ & $42(6 \%) \mathrm{A}$ & $16(4 \%)$ & $31(4 \%)$ & $48(4 \%) \mathrm{A}$ \\
\hline $6-9$ & $90(12 \%)$ & $87(12 \%)$ & $31(7 \%)$ & $49(7 \%)$ & $81(7 \%)$ \\
\hline $9-12$ & $20(3 \%) \mathrm{B}$ & $20(3 \%) \mathrm{B}$ & $20(5 \%)$ & $25(4 \%)$ & $45(4 \%) \mathrm{A}$ \\
\hline $12-17$ & 0 & $8(1 \%)$ & $1(0.2 \%)$ & $26(4 \%)$ & $27(2 \%)$ \\
\hline Total & $780(100 \%) \mathrm{B}$ & $714(100 \%) \mathrm{B}$ & $422(100 \%)$ & $697(100 \%)$ & $1127(100 \%) \mathrm{A}$ \\
\hline
\end{tabular}

The percentage of root mass in each soil layer relative to the total root mass is in parentheses. Different letters indicate significant differences between treatments in each soil layer $(\mathrm{p}<0.05)$

to 6 times higher in $50 \mathrm{~A} 50 \mathrm{E}$ than in $100 \mathrm{~A}$ down to a depth of $2 \mathrm{~m}$ while the differences between treatments decreased at depths $>2 \mathrm{~m}$ (Fig. 4). The highest difference between the $A$. mangium root traits in 50A50E and in $100 \mathrm{~A}$ was in the topsoil. In the top $0.5 \mathrm{~m}$ layer, the mean SRL of A. mangium fine roots was $72 \mathrm{~m} \mathrm{~g}^{-1}$ in 50A50E vs $11 \mathrm{~m} \mathrm{~g}^{-1}$ in 100A and the mean SRA was $848 \mathrm{~cm}^{2} \mathrm{~g}^{-1}$ in 50A50E vs $187 \mathrm{~cm}^{2} \mathrm{~g}^{-1}$ in 100A. Even though the mean diameter of $A$. mangium roots was higher in $100 \mathrm{~A}$ than in $50 \mathrm{~A} 50 \mathrm{E}$ in all the soil layers down to a depth of $6 \mathrm{~m}$, the differences between treatments were not significant in each individual layer (Figs. 4 and 5).

\section{Capacity to explore soil patches}

Mean fine-root production in the ingrowth bags reached $0.048 \pm 0.025 \mathrm{~g} \mathrm{dm}^{-3}$ month $^{-1}$ in 50A50E across the two trimesters and the four depths studied and was $63 \%$ higher than the average of 100A and 100E (Fig. 6). Surprisingly, the effect of soil depth on fine-root production in the ingrowth bags was not significant. Fineroot production in the ingrowth bags increased by $268 \%$ in $100 \mathrm{~A}, 42 \%$ in $100 \mathrm{E}$ and $33 \%$ in $50 \mathrm{~A} 50 \mathrm{E}$ from the first 3-month period (winter, dry season) to the second (spring). Fine-root production was significantly higher in $100 \mathrm{E}$ and $50 \mathrm{~A} 50 \mathrm{E}$ than in $100 \mathrm{~A}$. In individual soil layers, fine-root production was not significantly different between 50A50E and 100E, but significantly higher than in $100 \mathrm{~A}$ at depths $3-3.35 \mathrm{~m}$ and $6-6.35 \mathrm{~m}$ in winter and at depths $0.1-0.45 \mathrm{~m}$ and $1-1.35 \mathrm{~m}$ in spring.

The fine-root production of each species in 50A50E and $50 \%$ of the production in monospecific stands showed a strong seasonality (Fig. 6). While the production of $A$. mangium roots in winter in the ingrowth bags tended to be higher in $50 \mathrm{~A} 50 \mathrm{E}$ than $50 \%$ of that produced in 100A, it was lower in spring. The production of E. grandis roots in the ingrowth bags in winter was slightly higher in 50A50E than $50 \%$ of the root biomass produced in 100E in soil layers $1-1.35 \mathrm{~m}$ and 6-6.35 $\mathrm{m}$, and 5 times higher in the $3-3.35 \mathrm{~m}$ soil layer. In spring, the production of $E$. grandis roots in the ingrowth bags was 2-3 times higher in $50 \mathrm{~A} 50 \mathrm{E}$ than $50 \%$ of the production in $100 \mathrm{E}$ in the upper soil layers $(0.1-$ $0.45 \mathrm{~m}$ and $1-1.35 \mathrm{~m}$ depths) and close to $50 \%$ of the root production in 100E in deep soil layers (3-3.35 m and 6-6.35 $\mathrm{m}$ depths).

\section{Discussion}

Fine-root over-yielding in very deep soil layers

The main purpose of this study was to investigate whether roots explore very deep soil layers more intensively in mixed-species stands than in monospecific 


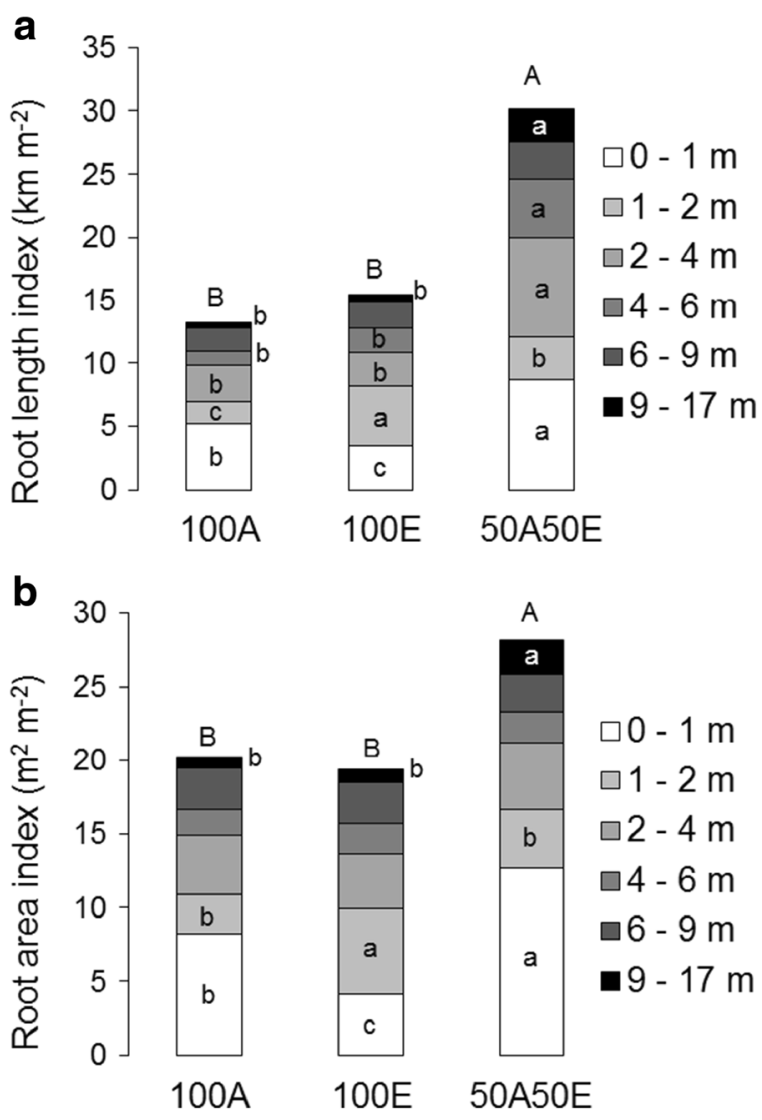

Fig. 5 Root length index $\left(\mathrm{km} \mathrm{m}^{-2}\right)$ a) and root area index $\left(\mathrm{m}^{2} \mathrm{~m}^{-2}\right) \mathrm{b}$ ) in the 0-1 $\mathrm{m}, 1-2 \mathrm{~m}, 2-4 \mathrm{~m}, 4-6 \mathrm{~m}, 6-9 \mathrm{~m}$ and 9$17 \mathrm{~m}$ soil layers for Acacia mangium monospecific stands (100A), Eucalyptus grandis monospecific stands (100E) and the mixed stands (50A50E). Different upper-case letters indicate significant differences between treatments for the cumulative indices and different lower-case letters indicate significant differences between treatments within each individual soil layer $(\mathrm{p}<0.05)$

stands. In agreement with our first hypothesis, mixing A. mangium and $E$. grandis trees led to a strong fine-root over-yielding in all soil layers down to the water table at a depth of $17 \mathrm{~m}$. Although fine-root over-yielding has already been reported in the upper soil layers for mixed stands compared to monospecific stands (Brassard et al. 2013; Laclau et al. 2013b; Lei et al. 2012), the opposite has also been reported (Bolte and Villanueva 2006), and other studies have shown similar fine-root biomasses in mixed and monospecific stands (Bauhus et al. 2000; Meinen et al. 2009). A recent global meta-analysis across forests, grasslands, croplands and pot systems showed that mixed stands had, on average $28 \%$ higher fine-root biomass and $45 \%$ higher annual production than monocultures (Ma and Chen 2016). The originality of our results come from the strong fine-root over- yielding observed in soil layers at depths $>2 \mathrm{~m}$. Competition for water and nutrients with the neighboring trees in mixed stands may force the roots to explore and tap deep soil layers (Cardinael et al. 2015; Ma and Chen 2017). While most of the studies dealing with fineroot distribution in forests have been limited to the upper $2 \mathrm{~m}$ of soil, $35 \%, 45 \%$ and $50 \%$ of the total fine-root biomass was found below $2 \mathrm{~m}$ in 100A, 50A50E and $100 \mathrm{E}$, respectively. The difficulty of sampling deep roots can lead to underestimates of root mass and belowground productivity in tropical plantations and forests (Maeght et al. 2015; Pierret et al. 2016). Studies quantifying total fine-root biomass down to the root front are scarce for trees growing in very deep tropical soils. Close to our study site (on the same soil type), the proportion of fine roots below $2 \mathrm{~m}$ depth was $20-30 \%$ of the total fine-root biomass down to the root front in a sweet orange orchard (Adriano et al. 2017) and 30-60\% of the total fine-root length, depending on tree age, in eucalypt plantations (Laclau et al. 2013a; Pinheiro et al. 2016). As commonly reported in forest ecosystems, fine-root densities dropped rapidly within the first topsoil layers then decreased gradually with soil depth, which corresponds to the distribution of nutrients in soil profiles (Weemstra et al. 2017). Interactions between tree species greatly increase the exploration of very deep soil layers in our study, which is likely to enhance the uptake of soil resources. Establishing a deep root system can also help tropical trees withstand the prolonged droughts that are expected to increase in the future (Christina et al. 2017; Solomon et al. 2009). A modeling approach in a nearby eucalypt stand of similar productivity showed that very low densities of fine roots at depths $>10 \mathrm{~m}$ can withdraw substantial amounts of water during dry periods (Christina et al. 2017). Mixing tree species could therefore enhance the resilience of tropical planted forests to climate changes increasing the access to water and nutrients stored in very deep soil layers.

Fine-root over-yielding in 50A50E is also consistent with the higher soil respiration rates relative to $100 \mathrm{~A}$ and $100 \mathrm{E}$ at the end of the previous rotation (Nouvellon et al. 2012). Roots are a major contributor to soil respiration (Gill et al. 2002; Marsden et al. 2008) and about $25 \%$ of terrestrial net primary production is due to fineroot production and turnover (McCormack et al. 2015). The total belowground $\mathrm{C}$ fluxes from 4 to 6 years after planting in the previous rotation of our experiment represented $24 \%, 26 \%$ and $32 \%$ of the gross primary 
a

Trimester 1

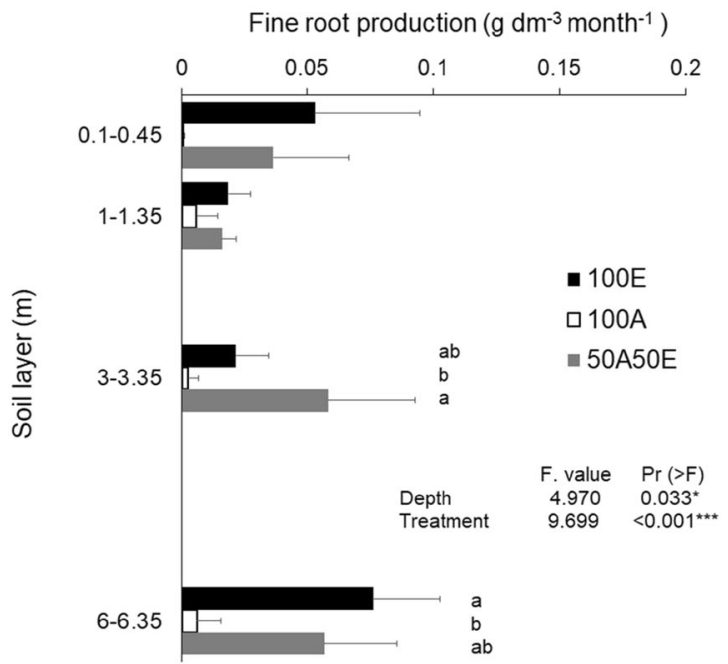

b Species-specific fine root production relative to monospecific stands (\%)

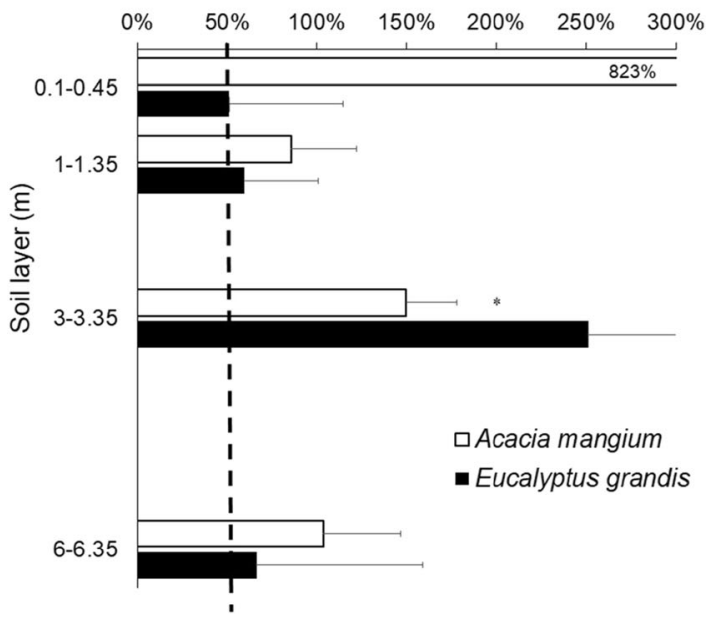

Fig. 6 Fine root production $\left(\mathrm{g} \mathrm{dm}^{-3} \mathrm{month}^{-1}\right)$ in ingrowth bags down to a depth of $6.35 \mathrm{~m}$ in 100E (filled black bars), 100A (open bars) and 50A50E (filled grey bars) (a) and percentages of fineroot production in $50 \mathrm{~A} 50 \mathrm{E}$ relative to the production in each soil layer for the single-species stands (b) in winter (dry season; Trimester 1, left) and in spring (Trimester 2, right). Significant differences between treatments in the same soil layer are indicated by different letters $(\mathrm{p}<0.05)$. The dotted lines indicate the $50 \%$ reference for Acacia mangium roots (open bars with standard

production in $100 \mathrm{~A}, 100 \mathrm{E}$ and $50 \mathrm{~A} 50 \mathrm{E}$, respectively (Nouvellon et al. 2012). Large amounts of C are stored at great depths in tropical soils (Batjes 2014) and changes in land use increasing the supply of fresh carbon might promote the activity of microbes through a priming effect (Derrien et al. 2014; Fontaine et al. 2007). The
Trimester 2

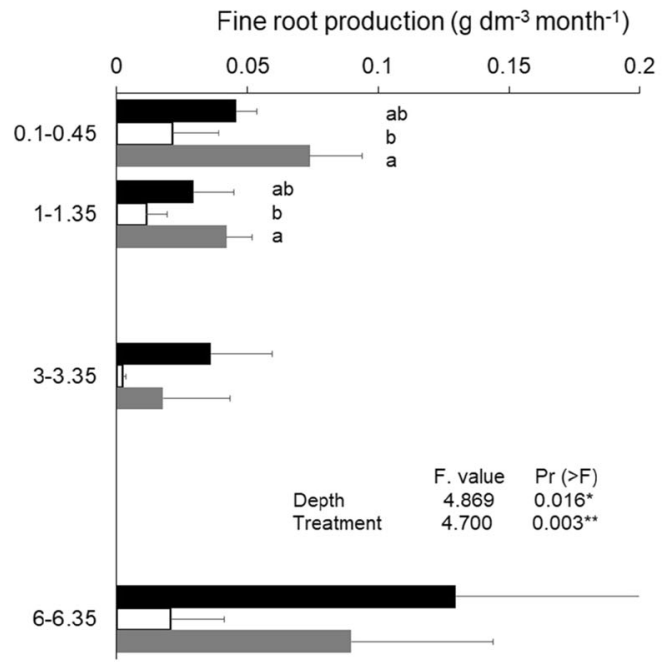

Species-specific fine root production relative to monospecific stands (\%)

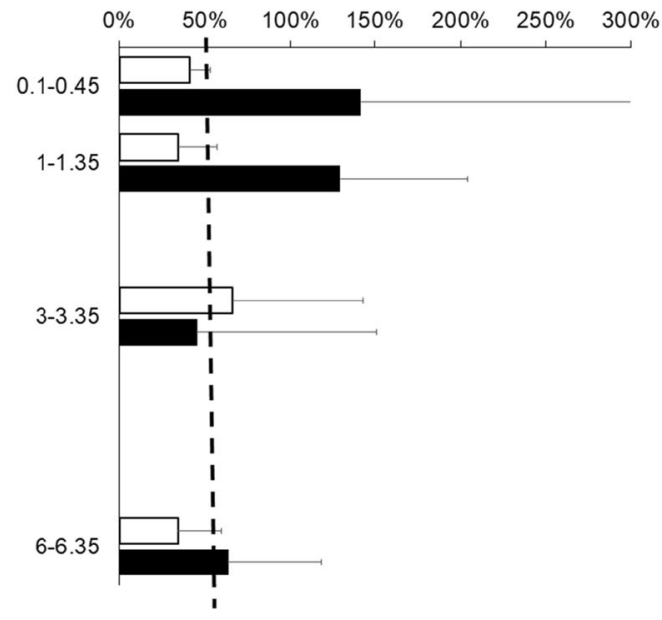

errors) and Eucalyptus grandis roots (solid bars with standard errors) if root development was similar to the monoculture, for a $50 \%$ stocking density for each species. Standard error bars are shown $(\mathrm{n}=3)$. Asterisks $*$ denotes a significant difference $(\mathrm{P}<0.05)$ between the root biomass of a particular species in $50 \mathrm{~A} 50 \mathrm{E}$ and $50 \%$ of the biomass at the same positions in the pure stands of the same species. F and $P$ values of linear mixed models for fine-root production $\left(\mathrm{g} \mathrm{dm}^{-3} \mathrm{month}^{-1}\right)$ as a function of soil depth and treatment are shown

increase in fine-root biomass, by replacing monospecific stands by mixed-species, may have consequences on soil carbon sequestration in deep soil layers that are poorly understood. Further studies are needed to assess whether an increase in the release of fresh $\mathrm{C}$ in very deep soil layers resulting from the combination of tree species 
could contribute to mitigating climate change through a sequestration of $\mathrm{C}$ or, on the contrary, would promote the mineralization of ancient $\mathrm{C}$ and therefore increase $\mathrm{CO}_{2}$ emissions.

Root strategies in response to intra- and inter-specific interactions

In agreement with our second hypothesis, the interaction mechanisms between $E$. grandis and A. mangium trees led to large changes in A. mangium fine-root morphology. Previous studies at the same experimental site showed that $E$. grandis trees dominate the competition with $A$. mangium trees capturing more light per tree and taking advantage of $\mathrm{N}$ fixation (Paula et al. 2015). The A. mangium leaves are below the canopy of eucalypt trees in mixed stands and fine roots are partially excluded from the upper soil layer (Laclau et al. 2013b; Le Maire et al. 2013). A. mangium trees adopt an intensification strategy (Bonifas and Lindquist 2009; Lei et al. 2012; Ostonen et al. 2007) in competition with eucalypts, making it possible to increase the capacity to take up soil resources for a relatively low investment in belowground biomass. SRL and SRA of $A$. mangium fine roots in mixed stands were 2-3 times higher than in monoculture, which, in combination with a large increase in FRD, led to a much higher root length index and root area index. While some studies in forest ecosystems also showed higher SRL and SRA in mixed stands than in monospecific stands, making it possible to reduce the cost/benefit ratio for resource capture (Beyer et al. 2013; Lei et al. 2012; Sun et al. 2017; Weemstra et al. 2016), those root traits were similar in mixed-species plantations and monocultures of A. mearnsii and E. globulus in Australia (Bauhus et al. 2000). In our study, A. mangium faced competition with E. grandis by altering the root absorption capacity, much more through morphological adaptations than changing the fine-root biomass of each A. mangium tree.

$\mathrm{C}$ starvation affecting the fine root architecture of A. mangium trees dominated by eucalypts as well as changes in mycorrhizal status seem to be potential factors. A recent study carried out in the same experiment showed large changes in the microbiological and chemical attributes of soil between the 100A and 50A50E treatments (Bini et al. 2013), which suggests that changes in mycorrhizal status might be contribute to explaining the effect of eucalypts on the SRL and SRA of $A$. mangium roots. However, the mycorrhizal status was not directly measured and we can only speculate about this effect. Differences in nodulation might contribute to explaining this pattern. Indeed, nodule density was much higher in monospecific A. mangium stands than in mixed A. mangium and E. grandis stands in the previous rotation at this site (Bouillet et al. 2008). However, nodules were mainly observed in the $0-50 \mathrm{~cm}$ soil layer and their density was low in the scanned roots.

Our results confirm the fine-root segregation between the two species in the mixed stand observed for the previous rotation at this site (da Silva et al. 2009; Laclau et al. 2013b), with a partial exclusion of A. mangium roots from the resource-rich upper soil layers in mixed stands and a higher exploration of deep soil layers. However, the methodology was less intensive than in the previous studies of this effect (only one distance to the trees was sampled here and the $0-50 \mathrm{~cm}$ soil layer was not divided in several layers).

Eucalyptus grandis trees respond to competition with $A$. mangium trees through both an extensification strategy, leading to a sharp increase in fine-root biomass relative to monospecific stands, and an intensification strategy, increasing the volume of capture of soil resources relative to the fine-root biomass. However, the changes in SRL, SRA and fine-root diameter were non-significant in most of the soil layers, which suggests that the contribution of the intensification strategy was low. SRL and SRA values in our study are in the range reported down to a depth of $12 \mathrm{~m}$ for four Eucalyptus genotypes in nearby plantations (Pinheiro et al. 2016). The total biomass of E. grandis fine roots was similar in $50 \mathrm{~A} 50 \mathrm{E}$ and in $100 \mathrm{E}$ despite a stocking density of eucalypt trees twice as high in 100E, which shows a remarkable plasticity of eucalypt trees to explore a huge soil volume, as already shown in Laclau et al. (2013b). In boreal forests, a comparison of fine-root production in mixed and single-species stands showed that fine-root production was correlated with nitrogen concentrations in the soil layers, and suggested that an enhancement of $\mathrm{N}$ availability in the mixed stands contributed to increasing fine-root production (Ma and Chen 2017). We, therefore, speculate that facilitation mechanisms for $E$. grandis trees planted with A. mangium resulting from an increase in soil $\mathrm{N}$ availability (Tchichelle et al. 2017; Voigtlaender et al. 2012), could be involved in the extensification strategy leading to an increase in soil exploration by E. grandis fine roots. Such pattern might be 
pronounced in the superficial soil layers where eucalypt trees benefit from a rapid belowground $\mathrm{N}$ transfer from A. mangium trees (Paula et al. 2015).

While many studies show that SRL, SRA and fineroot diameter can change depending on soil depth (Bakker et al. 2009; Makita et al. 2011; Maurice et al. 2010; Prieto et al. 2015), we did not observe clear patterns down the soil profile for either species. The same type of study carried out down to the root front in other eucalypt and orange plantations in Brazil also showed a high variability of SRL, SRA and fine-root diameter between soil layers but without a clear correlation with the depth (Adriano et al. 2017; Pinheiro et al. 2016). A study carried out in 20 plant communities sampled in tropical, Mediterranean and montane regions showed that some fine-root traits were significantly different between shallow and deep soil layers, but absolute differences were small for most of the traits measured (Prieto et al. 2015). Our results suggest that E. grandis and A. mangium fine roots in mixed stands reflect an acquisitive resource strategy (Freschet et al. 2017; McCormack et al. 2015). Further studies in eucalypt and acacia plantations should examine other important root traits (in particular tissue density, concentrations of nutrients, cellulose, lignin and carbohydrate) to gain insight into the cost to the trees of investing in fineroot production in very deep soil layers.

Fine-root production

Even though the fine-root production of A. mangium and E. grandis trees exhibited a strong seasonal variability, the decrease in fine-root density with soil depth did not modify the production of fine roots in the ingrowth bags down to a depth of $6 \mathrm{~m}$. This pattern is contrary to our third hypothesis and shows a huge capacity of very deep roots to explore resource-rich soil patches despite their low density in the soil. The production of fine roots in the ingrowth bags was however much higher for E. grandis trees than for A. mangium trees, which is consistent with the faster growth rates of E. grandis trees shown both aboveground and belowground (da Silva et al. 2009; Nouvellon et al. 2012). Fine-root production in the ingrowth bags confirmed the strong over-yielding in mixed-species stands relative to the monocultures suggested by the fine-root densities. However, fine roots sampled in ingrowth bags can be different from fine roots sampled in undisturbed soil and productions estimated from ingrowth bags should be interpreted with caution (Bauhus and Messier 1999; Jourdan et al. 2008). Nevertheless, the same ingrowth bags were installed at all the depths in all the treatments, making it possible to compare the capacity of fine roots to explore soil patches.

The production of A. mangium fine roots in the ingrowth bags was much more affected by the season (winter vs spring) in the topsoil than in deep soil layers, as reported for phreatophytic species (Canham et al. 2012). E. grandis trees are better adapted to the cold climate in winter at our study site than A. mangium trees, which could account for the higher fine-root production in the topsoil in E. grandis monoculture and mixed-species stands than in A. mangium monoculture. A strong influence of exogenous factors such as soil temperature and water content (Canham et al. 2015), as well as endogenous factors such as photosynthate availability, on fine-root phenology is well documented (McCormack et al. 2015).

In conclusion, our study shows that mixing species can lead to a strong fine-root over-yielding in very deep soil layers. We demonstrate that $E$. grandis and $A$. mangium trees growing in mixed stands can explore more intensively deep soil layers than their respective monospecific stands. Studies dealing with deep rooting are needed for other tree species, soils and climates to assess whether increasing the diversity in tropical planted forests could increase their resilience to climate change by providing access to more soil resources than monospecific stands. A better comprehension of the effects of fine-root growth and turnover in very deep soil layers on soil carbon stocks is also needed to better assess the long-term consequences of afforestation with fast-growing tree species on the global carbon cycle.

Acknowledgements We are truly grateful to Daise Silva Ferreira for the huge work carried out in the field and in the laboratory. We would like to thank Agence national de la recherche (Intens\&fix Project ANR-2010-STRA-004-03) and São Paulo Research foundation (FAFESP, projects 2015/24911-8 and 2011/20510-8) for their financial support. The study belongs to the SOERE F-ORE-T, which is supported annually by Ecofor, Allenvi and the French National Research Infrastructure ANAEEF (http://www.anaee-france.fr/fr/). We are grateful of the technical support of Rildo M. Moreira and the staff of Itatinga Research Station (ESALQ/USP) as well as Eder Araujo da Silva (http://www.floragroapoio.com.br). 


\section{Appendix}

Fig. 7 Root ingrowth bags at the four sampled depths

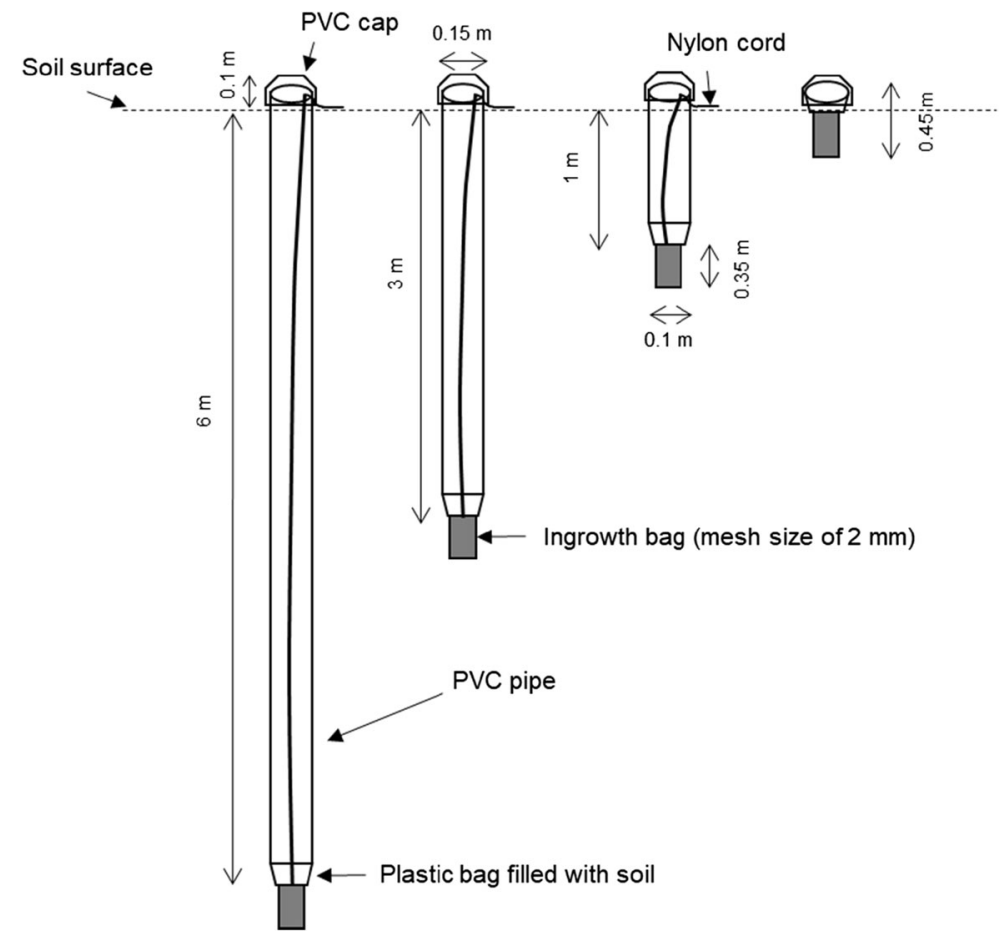

\section{References}

Adriano E, Laclau J-P, Rodrigues JD (2017) Deep rooting of rainfed and irrigated orange trees in Brazil. Trees 31:285-297

Bakker M, Jolicoeur E, Trichet P, Augusto L, Plassard C, Guinberteau J, Loustau D (2009) Adaptation of fine roots to annual fertilization and irrigation in a 13-year-old Pinus pinaster stand. Tree Physiol 29:229-238

Batjes N (2014) Total carbon and nitrogen in the soils of the world. Eur J Soil Sci 65:10-21

Battie-Laclau P, Laclau JP, Domec JC, Christina M, Bouillet JP, Cassia Piccolo M, Moraes Gonçalves JL, Krusche AV, Bouvet JM, Nouvellon Y (2014) Effects of potassium and sodium supply on drought-adaptive mechanisms in Eucalyptus grandis plantations. New Phytol 203:401-413

Bauhus J, Messier C (1999) Soil exploitation strategies of fine roots in different tree species of the southern boreal forest of eastern Canada. Can J For Res 29:260-273

Bauhus J, Khanna P, Menden N (2000) Aboveground and belowground interactions in mixed plantations of Eucalyptus globulus and Acacia mearnsii. Can J For Res 30:1886-1894

Bauhus J, Van Winden AP, Nicotra AB (2004) Aboveground interactions and productivity in mixed-species plantations of Acacia mearnsii and Eucalyptus globulus. Can J For Res 34:686-694

Beyer F, Hertel D, Leuschner C (2013) Fine root morphological and functional traits in Fagus sylvatica and Fraxinus excelsior saplings as dependent on species, root order and competition. Plant Soil 373:143-156
Bini D, Dos Santos CA, Bouillet J-P, de Morais Goncalves JL, Cardoso EJBN (2013) Eucalyptus grandis and Acacia mangium in monoculture and intercropped plantations: evolution of soil and litter microbial and chemical attributes during early stages of plant development. Appl Soil Ecol 63:57-66

Binkley D, Campoe OC, Gspaltl M, Forrester DI (2013) Light absorption and use efficiency in forests: why patterns differ for trees and stands. For Ecol Manag 288:5-13

Blaser WJ, Shanungu GK, Edwards PJ, Venterink HO (2014) Woody encroachment reduces nutrient limitation and promotes soil carbon sequestration. Ecol Evol 4:1423-1438. https://doi.org/10.1002/ece3.1024

Bolte A, Villanueva I (2006) Interspecific competition impacts on the morphology and distribution of fine roots in European beech (Fagus sylvatica L.) and Norway spruce (Picea abies (L.) Karst.) Eur J For Res 125:15-26

Bonifas KD, Lindquist JL (2009) Effects of nitrogen supply on the root morphology of corn and velvetleaf. J Plant Nutr 32: 1371-1382

Booth TH (2013) Eucalypt plantations and climate change. For Ecol Manag 301:28-34

Bouillet J-P, Laclau J-P, Gonçalves JLM, Moreira M, Trivelin P, Jourdan C, Silva E, Piccolo MC, Tsai S, Galiana A (2008) Mixed-species plantations of Acacia Mangium and Eucalyptus Grandis in Brazil: 2: nitrogen accumulation in the stands and biological N2 fixation. For Ecol Manag 255: 3918-3930

Bouillet J-P, Laclau J-P, Gonçalves JLM, Voigtlaender M, Gava JL, Leite FP, Hakamada R, Mareschal L, Mabiala A, Tardy 
F, Levillain J, Deleporte P, Epron D, Nouvellon Y (2013) Eucalyptus and acacia tree growth over entire rotation in single- and mixed-species plantations across five sites in Brazil and Congo. For Ecol Manag 301:89-101. https://doi.org/10.1016/j.foreco.2012.09.019

Brassard BW, Chen HY, Cavard X, Jo L, Reich PB, Bergeron Y, Pare D, Yuan Z (2013) Tree species diversity increases fine root productivity through increased soil volume filling. J Ecol 101:210-219

Brunner I, Bakker MR, Björk RG, Hirano Y, Lukac M, Aranda X, Børja I, Eldhuset TD, Helmisaari H-S, Jourdan C (2013) Fine-root turnover rates of European forests revisited: an analysis of data from sequential coring and ingrowth cores. Plant Soil 362:357-372

Canham CA, Froend RH, Stock WD, Davies M (2012) Dynamics of phreatophyte root growth relative to a seasonally fluctuating water table in a Mediterraneantype environment. Oecologia 170:909-916. https://doi.org/10.1007/s00442-012-2381-1

Canham CA, Froend RH, Stock WD (2015) Rapid root elongation by phreatophyte seedlings does not imply tolerance of water table decline. Trees 29:815-824. https://doi.org/10.1007/s00468-015-1161-z

Cardinael R, Mao Z, Prieto I, Stokes A, Dupraz C, Kim JH, Jourdan C (2015) Competition with winter crops induces deeper rooting of walnut trees in a Mediterranean alley cropping agroforestry system. Plant Soil 391:219-235

Christina M, Laclau J-P, Gonçalves J, Jourdan C, Nouvellon Y, Bouillet J-P (2011) Almost symmetrical vertical growth rates above and below ground in one of the world's most productive forests. Ecosphere 2:1-10

Christina M, Nouvellon Y, Laclau J-P, Stape JL, Bouillet J-P, Lambais GR, le Maire G, Tjoelker M (2017) Importance of deep water uptake in tropical eucalypt forest. Funct Ecol 31: 509-519. https://doi.org/10.1111/1365-2435.12727

da Silva EV, de Moraes Gonçalves JL, de Freitas Coelho SR, e Moreira RM, de Miranda Mello SL, Bouillet J-P, Jourdan C, Laclau J-P (2009) Dynamics of fine root distribution after establishment of monospecific and mixed-species plantations of Eucalyptus grandis and Acacia mangium. Plant Soil 325: 305-318

Derrien D, Plain C, Courty P-E, Gelhaye L, Moerdijk-Poortvliet TCW, Thomas F, Versini A, Zeller B, Koutika L-S, Boschker HTS, Epron D (2014) Does the addition of labile substrate destabilise old soil organic matter? Soil Biol Biochem 76: 149-160. https://doi.org/10.1016/j.soilbio.2014.04.030

Epron D, Nouvellon Y, Mareschal L, Moreira RM, Koutika LS, Geneste B, Delgado-Rojas JS, Laclau J-P, Sola G, Gonçalves JLM, Bouillet J-P (2013) Partitioning of net primary production in eucalyptus and acacia stands and in mixed-species plantations: two case-studies in contrasting tropical environments. For Ecol Manag 301:102-111. https://doi.org/10.1016/j.foreco.2012.10.034

Fontaine S, Barot S, Barré P, Bdioui N, Mary B, Rumpel C (2007) Stability of organic carbon in deep soil layers controlled by fresh carbon supply. Nature 450:277-280

Forrester DI (2014) The spatial and temporal dynamics of species interactions in mixed-species forests: from pattern to process. For Ecol Manag 312:282-292
Forrester DI, Bauhus J, Cowie AL, Vanclay JK (2006) Mixedspecies plantations of eucalyptus with nitrogen-fixing trees: a review. For Ecol Manag 233:211-230

Freschet GT, Valverde-Barrantes OJ, Tucker CM, Craine JM, McCormack ML, Violle C, Fort F, Blackwood CB, UrbanMead KR, Iversen CM, Bonis A, Comas LH, Cornelissen JHC, Dong M, Guo D, Hobbie SE, Holdaway RJ, Kembel SW, Makita N, Onipchenko VG, Picon-Cochard C, Reich PB, Riva EG, Smith SW, Soudzilovskaia NA, Tjoelker MG, Wardle DA, Roumet C (2017) Climate, soil and plant functional types as drivers of global fine-root trait variation. $\mathrm{J}$ Ecol. https://doi.org/10.1111/1365-2745.12769

Gill RA, Polley HW, Johnson HB, Anderson LJ, Maherali H, Jackson RB (2002) Nonlinear grassland responses to past and future atmospheric $\mathrm{CO} 2$. Nature 417:279-282

Gonçalves JLM, Alvares CA, Higa AR, Silva LD, Alfenas AC, Stahl J, de Barros Ferraz SF, de Paula Lima W, PHS B, Hubner A (2013) Integrating genetic and silvicultural strategies to minimize abiotic and biotic constraints in Brazilian eucalypt plantations. For Ecol Manag 301:6-27

Hodge A (2004) The plastic plant: root responses to heterogeneous supplies of nutrients. New Phytol 162:9-24

IBA (2016) Brazilian tree industry. http://iba. org/images/shared/Biblioteca/IBA_RelatorioAnual2016_. pdf. Accessed 29 jan 2017

Jackson RB, Mooney H, Schulze E-D (1997) A global budget for fine root biomass, surface area, and nutrient contents. Proc Natl Acad Sci 94:7362-7366

Jourdan C, Silva E, Gonçalves JLM, Ranger J, Moreira R, Laclau J-P (2008) Fine root production and turnover in Brazilian eucalyptus plantations under contrasting nitrogen fertilization regimes. For Ecol Manag 256:396-404

Keenan RJ, Reams GA, Achard F, de Freitas JV, Grainger A, Lindquist E (2015) Dynamics of global forest area: results from the FAO global forest resources assessment 2015. For Ecol Manag 352:9-20

Kell DB (2012) Large-scale sequestration of atmospheric carbon via plant roots in natural and agricultural ecosystems: why and how. Philos Trans R Soc B 367:1589-1597

Kuznetsova A, Brockhoff PB, Christensen RHB (2015) lmerTest: tests in linear mixed effects models. $\mathrm{R}$ package version 2.033. https://CRAN.Rproject.org/package=lmerTest. Accessed 10 Jul 2017

Laclau J-P, Bouillet J-P, Gonçalves J, Silva E, Jourdan C, Cunha M, Moreira M, Saint-André L, Maquère V, Nouvellon Y (2008) Mixed-species plantations of Acacia mangium and Eucalyptus grandis in Brazil: 1. Growth dynamics and aboveground net primary production. For Ecol Manag 255:3905-3917

Laclau J-P, Ranger J, de Moraes Goncalves JL, Maquere V, Krusche AV, M'Bou AT, Nouvellon Y, Saint-Andre L, Bouillet J-P, de Cassia PM (2010) Biogeochemical cycles of nutrients in tropical eucalyptus plantations: main features shown by intensive monitoring in Congo and Brazil. For Ecol Manag 259:1771-1785

Laclau JP, da Silva EA, Rodrigues Lambais G, Bernoux M, le Maire G, Stape JL, Bouillet JP, Goncalves JL, Jourdan C, Nouvellon Y (2013a) Dynamics of soil exploration by fine roots down to a depth of $10 \mathrm{~m}$ throughout the entire rotation in Eucalyptus grandis plantations. Front Plant Sci 4:243. https://doi.org/10.3389/fpls.2013.00243

Laclau JP, Nouvellon Y, Reine C, Goncalves JL, Krushe AV, Jourdan C, le Maire G, Bouillet JP (2013b) Mixing 
eucalyptus and acacia trees leads to fine root over-yielding and vertical segregation between species. Oecologia 172: 903-913. https://doi.org/10.1007/s00442-012-2526-2

Le Maire G, Nouvellon Y, Christina M, Ponzoni FJ, Gonçalves JLM, Bouillet J-P, Laclau J-P (2013) Tree and stand light use efficiencies over a full rotation of single-and mixed-species Eucalyptus grandis and Acacia mangium plantations. For Ecol Manag 288:31-42

Lehmann J (2003) Subsoil root activity in tree-based cropping systems. Plant Soil 255:319-331

Lei P, Scherer-Lorenzen M, Bauhus J (2012) Belowground facilitation and competition in young tree species mixtures. For Ecol Manag 265:191-200. https://doi.org/10.1016/j.foreco.2011.10.033

Ma Z, Chen HY (2016) Effects of species diversity on fine root productivity in diverse ecosystems: a global meta-analysis. Glob Ecol Biogeogr 25:1387-1396

Ma Z, Chen HY (2017) Effects of species diversity on fine root productivity increase with stand development and associated mechanisms in a boreal forest. J Ecol 105:237-245

Maeght JL, Gonkhamdee S, Clement C, Isarangkool Na Ayutthaya S, Stokes A, Pierret A (2015) Seasonal Patterns of Fine Root Production and Turnover in a Mature Rubber Tree (Hevea brasiliensis Mull. Arg.) Stand-Differentiation with Soil Depth and Implications for Soil Carbon Stocks. Front Plant Sci 6:1022. https://doi.org/10.3389/fpls.2015.01022

Makita N, Hirano Y, Mizoguchi T, Kominami Y, Dannoura M, Ishii H, Finér L, Kanazawa Y (2011) Very fine roots respond to soil depth: biomass allocation, morphology, and physiology in a broad-leaved temperate forest. Ecol Res 26:95-104

Maquere V (2008) Dynamics of mineral elements under a fastgrowing eucalyptus plantation in Brazil. Implications for soil sustainability. Ph.D. Thesis, Agroparitech, Paris

Marsden C, Nouvellon Y, M'Bou AT, Saint-Andre L, Jourdan C, Kinana A, Epron D (2008) Two independent estimations of stand-level root respiration on clonal eucalyptus stands in Congo: up scaling of direct measurements on roots versus the trenched-plot technique. New Phytol 177:676-687

Maurice J, Laclau J-P, Re DS, de Moraes Gonçalves JL, Nouvellon Y, Bouillet J-P, Stape JL, Ranger J, Behling M, Chopart J-L (2010) Fine root isotropy in Eucalyptus grandis plantations. Towards the prediction of root length densities from root counts on trench walls. Plant Soil 334:261-275

McCormack ML, Guo D (2014) Impacts of environmental factors on fine root lifespan. Front Plant Sci 5:205

McCormack ML, Dickie IA, Eissenstat DM, Fahey TJ, Fernandez CW, Guo D, Helmisaari HS, Hobbie EA, Iversen CM, Jackson RB, Leppalammi-Kujansuu J, Norby RJ, Phillips RP, Pregitzer KS, Pritchard SG, Rewald B, Zadworny M (2015) Redefining fine roots improves understanding of below-ground contributions to terrestrial biosphere processes. New Phytol 207:505-518. https://doi.org/10.1111/nph.13363

McDowell N, Pockman WT, Allen CD, Breshears DD, Cobb N, Kolb T, Plaut J, Sperry J, West A, Williams DG (2008) Mechanisms of plant survival and mortality during drought: why do some plants survive while others succumb to drought? New Phytol 178:719-739

Meinen C, Hertel D, Leuschner C (2009) Biomass and morphology of fine roots in temperate broad-leaved forests differing in tree species diversity: is there evidence of below-ground overyielding? Oecologia 161:99-111

Nouvellon Y, Laclau JP, Epron D, Le Maire G, Bonnefond JM, Goncalves JL, Bouillet JP (2012) Production and carbon allocation in monocultures and mixed-species plantations of Eucalyptus grandis and Acacia mangium in Brazil. Tree Physiol 32:680-695. https://doi.org/10.1093/treephys/tps041

Ostonen I, Lõhmus K, Helmisaari H-S, Truu J, Meel S (2007) Fine root morphological adaptations in scots pine, Norway spruce and silver birch along a latitudinal gradient in boreal forests. Tree Physiol 27:1627-1634

Paquette A, Messier C (2010) The role of plantations in managing the world's forests in the Anthropocene. Front Ecol Environ 8:27-34

Paula RR, Bouillet J-P, Ocheuze Trivelin PC, Zeller B, Leonardo de Moraes Gonçalves J, Nouvellon Y, Bouvet J-M, Plassard C, Laclau J-P (2015) Evidence of short-term belowground transfer of nitrogen from Acacia mangium to Eucalyptus grandis trees in a tropical planted forest. Soil Biol Biochem 91:99-108. https://doi.org/10.1016/j.soilbio.2015.08.017

Pierret A, Maeght JL, Clement C, Montoroi JP, Hartmann C, Gonkhamdee S (2016) Understanding deep roots and their functions in ecosystems: an advocacy for more unconventional research. Ann Bot. https://doi.org/10.1093 /aob/mcw130

Pinheiro RC, de Deus JC, Nouvellon Y, Campoe OC, Stape JL, Aló LL, Guerrini IA, Jourdan C, Laclau J-P (2016) A fast exploration of very deep soil layers by eucalyptus seedlings and clones in Brazil. For Ecol Manag 366:143-152. https://doi.org/10.1016/j.foreco.2016.02.012

Pradier C, Hinsinger P, Laclau J-P, Bouillet J-P, Guerrini IA, Gonçalves JLM, Asensio V, Abreu-Junior CH, Jourdan C (2017) Rainfall reduction impacts rhizosphere biogeochemistry in eucalypts grown in a deep Ferralsol in Brazil. Plant Soil 414:339-354

Pregitzer KS, DeForest JL, Burton AJ, Allen MF, Ruess RW, Hendrick RL (2002) Fine root architecture of nine north American trees. Ecol Monogr 72:293-309

Prieto I, Roumet C, Cardinael R, Dupraz C, Jourdan C, Kim JH, Maeght JL, Mao Z, Pierret A, Portillo N (2015) Root functional parameters along a land-use gradient: evidence of a community-level economics spectrum. J Ecol 103:361-373

Radville L, McCormack ML, Post E, Eissenstat DM (2016) Root phenology in a changing climate. J Exp Bot 67:3617-3628. https://doi.org/10.1093/jxb/erw062

Richards AE, Forrester DI, Bauhus J, Scherer-Lorenzen M (2010) The influence of mixed tree plantations on the nutrition of individual species: a review. Tree Physiol 30:1192-1208

Santos FM, de Carvalho BF, dos Santos Ataíde DH, Diniz AR, Chaer GM (2016) Dynamics of aboveground biomass accumulation in monospecific and mixed-species plantations of eucalyptus and acacia on a Brazilian sandy soil. For Ecol Manag 363:86-97

Solomon S, Plattner G-K, Knutti R, Friedlingstein P (2009) Irreversible climate change due to carbon dioxide emissions. Proc Natl Acad Sci 106:1704-1709

Sun Z, Liu X, Schmid B, Bruelheide H, Bu W, Ma K (2017) Positive effects of tree species richness on fine-root production in a subtropical forest in SE-China. J Plant Ecol 10:146-157

Tchichelle SV, Epron D, Mialoundama F, Koutika LS, Harmand JM, Bouillet J-P, Mareschal L (2017) Differences in nitrogen cycling and soil mineralisation between a eucalypt plantation 
and a mixed eucalypt and Acacia mangium plantation on a sandy tropical soil. South For J For Sci 79:1-8

Team R (2013) R development core team. RA Lang Environ Stat Comput 55:275-286

Voigtlaender M, Laclau J-P, de Moraes Gonçalves JL, de Cássia PM, Moreira MZ, Nouvellon Y, Ranger J, Bouillet J-P (2012) Introducing Acacia mangium trees in Eucalyptus grandis plantations: consequences for soil organic matter stocks and nitrogen mineralization. Plant Soil 352:99-111
Weemstra M, Mommer L, Visser EJ, Ruijven J, Kuyper TW, Mohren GM, Sterck FJ (2016) Towards a multidimensional root trait framework: a tree root review. New Phytol 211:1159-1169

Weemstra M, Sterck FJ, Visser EJ, Kuyper TW, Goudzwaard L, Mommer L (2017) Fine-root trait plasticity of beech (Fagus sylvatica) and spruce (Picea abies) forests on two contrasting soils. Plant Soil 415:175-188

Williams LJ, Paquette A, Cavender-Bares J, Messier C, Reich PB (2017) Spatial complementarity in tree crowns explains overyielding in species mixtures. Nat Ecol Evol 1:0063 